\title{
1 Fluid evolution in fracturing black shales, Appalachian Basin
}

2 John N. Hooker

3 Joe Cartwright

4 Ben Stephenson

5 Calvin R.P. Silver

$6 \quad$ Alexander J. Dickson

$7 \quad \mathrm{Yu}-\mathrm{Te}$ Hsieh

8

9 ABSTRACT

10

11 Opening-mode veins in cores drilled from the mudrocks over- and underlying the major Silurian salt décollement in the Appalachian plateau (Tioga and Lawrence Counties, Pennsylvania), have mineralogic and isotopic compositions generally matching those of their host mudrocks, suggesting opening and filling amid little cross-stratal fluid motion. Calcite and most trace minerals probably entered the veins via dissolution-reprecipitation from nearby host rock. Consistent with this interpretation are the observations that (i) trace minerals within the veins, including quartz, pyrite, and dolomite, are invariably also present within the layers hosting the veins, with vein cement minerals generally reflecting the abundance and solubility of minerals in the host-rock, and (ii) carbon and oxygen isotopic compositions of vein-filling calcite are similar to those of calcite within the host rock, with vein-filling $\delta^{18} \mathrm{O}$ slightly depleted and $\delta^{13} \mathrm{C}$ slightly enriched. Modeling the fluid isotopic evolution, assuming vein opening and filling amid immobile connate formation water, accounts for these minor but systematic differences, which are attributable to increasing temperature and hydrocarbon maturation. An exception to the above trend is barite, which, despite its low solubility, is systematically enriched in veins with respect to the host rock. It is unclear whether barite precipitation resulted from the influx of external fluids— — perhaps deriving from Silurian salt—or from barium mobilized at depth from local clays or organic material. 
Whether and how basin-scale fluid transport occurs has immense economic consequences, potentially

affecting the lateral and vertical distribution of hydrocarbons (Rabinowicz et al., 1985; Leythaeuser et al., 1995; Jung et al., 2015) and Mississippi Valley-type ore deposits (Cathles and Smith, 1983; Oliver, 1986, Héroux et al., 1996). Nearly universal trends in sediment permeability with depth, as well as diagenetic cements with host-rock lithology, suggest that subsurface fluid-flow is limited and relatively closed-system fluid behavior dominates (Bjørlykke, 2014). Most studies documenting significant fluid flow through the subsurface invoke enhanced permeability resulting from brittle deformation (Gleeson et al., 2003; Barker et al., 2006; Ryb et al., 2009; Vilasi et al., 2009; Dewever et al., 2013; Haeri-Ardakani et al., 2013; Wazir et al., 2014; Cai et al., 2015; Hooker et al., 2015; Jung et al., 2015; Worden et al., 2015). However, the presence of fractures does not necessitate that fluid flow has occurred, because it has long been appreciated that fractures may open and fill in a chemically closed system with little or no fluid transport (Dietrich et al., 1983; Czerniakowski et al., 1984; Banks et al., 1991; Gao et al., 1992; Lacazette and Engelder, 1992; Henry et al., 1996; Wiltschko and Morse, 2001; Blyth et al., 2004; Wangen and Munz, 2004; Verlaguet et al., 2011).

Isotopic and elemental concentration analyses of formation waters were interpreted to reflect fluid motion at the scale of the Appalachian Basin, possibly in response to tectonic compression (Osborn et al., 2012). It has been well documented that opening-mode fractures, having cm- to m-scale (inch- to foot-scale) length and $\mathrm{mm}$ - to cm-scale (up to inch-scale) displacement, are ubiquitous across the Appalachian Basin (Engelder et al., 2009; Evans et al., 2012; 2014; Wilkins et al., 2014). Fluid inclusion studies and field relations have revealed a dynamic interaction between crustal deformation and fluid pressure and flow, with widespread natural hydraulic fracturing occuring prior to (Engelder and Whitaker, 2006) and during (Evans, 2010; Wilkins et al., 2014) the development of the major regional fold-thrust belt. A major finding was that significant fluid flow occurred during fracturing, particularly during late-stage fold tightening and concomitant faulting (Evans et al., 2012; 2014). These faults cut across multiple stratigraphic intervals and resulted in mixing of previously isolated 
calcite (Goldstein and Reynolds, 1994), most reliable fluid-inclusion thermometry data in the basin

come from quartz crystals, whereas the dominant mineral in organic-rich mudrocks is calcite.

Therefore, although sub-seismic fractures are abundant in mudrocks, the timing and extent of fluid flow through such fractures is less certain. Consequently, the rates of natural fluid flow through mudrock layers, and the degree to which that flow is assisted by natural fractures, are largely unconstrained.

The goal of the present study is to compare mineralogic and isotopic compositions of core-derived calcite veins and their organic-rich host rocks, in order to determine whether and to what extent such sub-seismic-scale fractures might play a role in basin-scale fluid transport. In this study we present mineralogical, textural, and isotopic observations from opening-mode veins in Tioga County, northern Pennsylvania, within the Appalachian plateau (Figure 1). For perspective on the effects of folding, we also report data from cores containing veins within the sub-salt Ordovician Utica shale, from Lawrence County in western Pennsylvania. These veins were sampled from subsurface cores in prospective shale gas plays, thereby allowing us to address the extent of fracture-fluid transport in the subsurface of the relatively undeformed foreland, where faults are scarce relative to the hinterlandward Valley and Ridge province.

We find a general isotopic and mineralogic correspondence between the host-rock and vein fill, consistent with fracturing during progressively increasing temperature in a closed fluid system. Trace barite within veins presents an exception to this correspondence, and may signify either release of barium from organic matter or clay at depth, or minor influx of sulfate-bearing fluid during fracture opening. Modeling the isotopic evolution of formation waters through burial and incorporation of dissolved host-rock carbonate can explain the observed isotopic compositions of the veins without invoking external fluids. The results of this modeling and analysis suggest that variations in the isotopic compositions of veins and their host rocks reflect the fracture timing within the thermal histories of the rocks, even though the fluids have been generally isolated from outside sources. Moreover, this study emphasizes that veins, which may potentially facilitate or complicate 
hydrocarbon productivity from horizontal wells (Johri and Zoback, 2013; Gale et al., 2014; Stephenson et al., 2015), can form without the introduction of external fluids.

\section{GEOLOGIC SETTING}

The Appalachian Basin (Figure 1) formed during the Paleozoic on the eastern (present-day direction) margin of Laurentia. The Taconic, Acadian, and Alleghanian orogenies, during the OrdovicianSilurian, Devonian, and Pennsylvanian-Permian, respectively, transformed this passive margin into a foreland basin (Hatcher, 1981). The Grenville Province basement is overlain by passive margin basal siliciclastics and carbonates. An Ordovician unconformity is then overlain by more carbonates, and then in turn by the black mudstones of the Utica shale (Figure 2), which is at least $100 \mathrm{~m}$ (300 feet) thick in Lawrence County. This shale coarsens upward through the Ordovician and into Silurian sandstones, likely reflecting westward progression of the Taconic thrust belt (Bradley and Kusky, 1986).

Overlying carbonates had significant topographic relief related to reef facies, which sequestered seawater into evaporative basins (Ferguson and Prather, 1968; Indiana University Paleontology Seminar, 1976; Coniglio et al., 2004). These basins were depocenters for the salt beds and marine shales of the Salina group. Subsequent open-marine conditions are recorded in the Helderberg Group, which is topped by a regional unconformity (Diedrich and Wilkinson, 1999; Demicco and Smith, 2009).

During the Devonian, the Acadian orogeny brought multiple cycles of dominantly clastic sedimentation (Ettensohn, 1987). In the study area, the Oriskany sandstone is overlain by $\sim 7 \mathrm{~m}(\sim 20$ feet) of Onondaga limestone, a marine succession bearing chert beds as well as the regionally correlative Tioga bentonite (Oliver, 1954). The Onondaga Formation is overlain by the Marcellus shale. Structural highs to the west, and deposition sourced from the foreland, produced stratigraphic thickening of the Marcellus shale to the east (Wang and Carr, 2013), although Acadian reactivation of 
basement structures created locally increased accommodation and thickening throughout the basin (Lash and Engelder, 2011). The Marcellus shale is divided into upper and lower members, separated by the Cherry Valley limestone (Figure 2). In this study of subsurface cores we will use the terms Upper and Lower Marcellus; these are regionally correlable with the Oatka Creek Member and the Union Springs Member, respectively (Lash and Engelder, 2011). In the vicinity of Tioga county, the Lower Marcellus is roughly $100 \mathrm{~m}$ (300 feet) thick; the Upper Marcellus, $80 \mathrm{~m}$ (250 feet) thick. The Marcellus shale is overlain by the Devonian Hamilton shale and the Tully limestone, which tended to fold coherently with the Marcellus shale during the Alleghanian orogeny (Scanlin and Engelder, 2003; Evans et al., 2012).

Structurally, the Appalachian Basin can be divided into the Valley and Ridge province towards the hinterland and the Appalachian plateau towards the foreland (Sak et al., 2012). The boundary between the two runs SW-NE through central Pennsylvania (Figure 1), curving southward into Maryland and West Virginia and so forming the Pennsylvania salient (Rodgers, 1970). The Paleozoic section in both structural regions was folded into anticlines having tens of km-scale (tens of miles-scale) wavelength during the Alleghanian orogeny. In the Valley and Ridge province, these folds are detached over Cambro-Ordovician shales (Mount, 2014). The basal thrust fault cuts upsection into Silurian salts, over which folds in the Appalachian plateau are detached (Mount, 2014). Evidence from seismic and from analogous structures at the core scale are consistent with folds developing as kink bands (Faill, 1973; Mount, 2014; Gillespie et al., 2015; Stephenson and Coflin, 2015). The size and spacing of these salt-detached anticlines were probably affected by pre-existing sub-salt normal faults (Scanlin and Engelder, 2003).

Burial history modeling based on cores from the Appalachian plateau, within $100 \mathrm{~km}$ (60 miles) of the Valley and Ridge province, suggests a maximum burial for the Marcellus Formation of approximately $7 \mathrm{~km}\left(23,000\right.$ feet) and maximum temperatures near $200^{\circ} \mathrm{C}$ at the Permian-Triassic boundary, before 4 to $5 \mathrm{~km}$ (13,000 to 16,000 feet) of erosion (Wilkins et al., 2014). Evans et al. (2014) suggested that topographic highs in central Pennsylvania during the Permian account for relatively low thermal 
maturity there. In the present study area, $\sim 100 \mathrm{~km}$ ( $\sim 60$ miles) to the north, regional Marcellus

142 Formation vitrinite reflectance $\left(\mathrm{R}_{0}\right)$ near 2.0 (East et al., 2012) and a present-day depth from 1.5 to 1.8

$143 \mathrm{~km}(5000$ to 6000 feet $)$ is consistent with $4 \mathrm{~km}$ (10,000 feet) or more of exhumation, assuming no major changes in geothermal gradient or burial time-temperature integral in between.

Considerable previous work has been performed on fractures throughout the Appalachian Basin.

Layer-parallel, cement- and bitumen-filled fractures are common (Srivastava and Engelder, 1990; Lash and Engelder, 2005; Evans et al., 2014; Gale et al., 2014). Vertical fractures very broadly strike parallel (NE) and perpendicular (NW) to regional-scale anticlines (Figure 1). This pattern is present among non- or poorly-cemented joints in outcrop (Engelder et al., 2009) and among veins in outcrop and subsurface cores (Wilkins et al., 2014). Considerable fracture-strike variation is present towards the Valley and Ridge province (Evans et al., 2014), possibly resulting from a more complex fold geometry and higher strain there. Fringe cracks, formed by reoriented stress fields upon preexisting fractures, also introduce complexity to the regional fracture pattern (Younes and Engelder, 1999).

Fracture propagation in the Appalachian Basin is thought to predate and coincide with the

Alleghanian deformation that produced the regional-scale anticlines. A thrust-faulting stress regime is consistent with both the regional orogeny and the layer-parallel fractures, although cross-cutting relationships presented here and previous microstructural observations (Lash and Engelder, 2005) suggest a pre-folding timing to the veins, perhaps owing to catagenetic fluid overpressures (Lash and Engelder, 2005).

Fractures at high angle to fold axes (i.e., NW-striking fractures) are generally thought to have formed during folding, based on burial history modeling and fluid inclusion microthermometry (Evans, 1995, 2010; Evans et al., 2012, 2014; Wilkins et al., 2014) although there is still debate about the number and continuity of strain events that produced those veins (Wilkins et al., 2014) and the mechanics of vertical vein propagation within a thrust-faulting regime (Engelder et al., 2009; Wilkins et al., 2014). 
(i.e., NE-striking fractures) predate the folds, but abutting relationships in core (Evans, 1994) indicate NE-striking fractures that postdate NW-striking ones.

Evidence for widespread pressure solution throughout the Appalachian Basin takes the form of a layer-perpendicular stylolitic cleavage, recording layer-parallel shortening that is kinematically consistent with the Alleghanian folding (Engelder, 1979; Engelder and Geiser, 1984). This cleavage accounts for as much as $10 \%$ layer-parallel shortening in the Appalachian plateau of western New York (Engelder, 1979).

\section{METHODS}

Three cores, totaling $\sim 200 \mathrm{~m}$ ( $\sim 650$ feet) of Devonian section (Oriskany sandstone through Tully limestone-Figure 2) recovered, were examined. All three cores preserve the entire thickness of the Marcellus shale. We also report data from $\sim 130 \mathrm{~m}$ ( $\sim 430$ feet) of a single core drilled through the Utica shale. Core photos from a further 24 regional cores, part of a database gathered by a consortium based at Core Lab, Houston, Texas, were also examined for a basin-scale characterization of the vein pattern. Fractures were logged at the core scale using a hand lens and comparator for aperture measurement (Ortega et al., 2006). Missing core, either from incomplete recovery or previous sampling, potentially biases fracture surveys. To account for this bias as best we can, we quantify fracture abundance by normalizing summed fracture counts and sizes to the summed area of fracture core-face observed. Slabbed core faces are typically $75 \mathrm{~mm}$ (three inches) wide.

Calcite mineral fill was distinguished from quartz and barite using weak $\mathrm{HCl}$ and scratch tests. One core (F), was drilled at $\sim 45$ degrees from vertical (see schematic in Figure 2) and so permits evaluation of fracture strike. The two remaining Devonian cores (A and S), and the Ordovician core (P) were drilled vertically, so strike can only be verified for fractures detected on FMI logs. 
Here we refer to cemented, opening-mode fractures as veins. Cemented fractures having shear offset that can be estimated by displaced strata within core samples - i.e., less than a few $\mathrm{cm}$ - are referred to as shear veins. We reserve the term fault to describe large (m-scale (foot-scale) or greater) offset structures, which would likely be resolvable from seismic data. Many cores appear to intersect faults, based on the presence of partially mineralized or slickensided rubble zones (Figure 3E). To compare vein, shear vein, and fault frequency across the regional database, we logged fractures from photographs of slabbed core faces. Core-photo mineral identification was limited to distinguishing pyrite from other minerals by color (gold versus white), consistent with calibration between core samples and photos of Cores A, F, P, and S.

We analyzed veins in thin sections cut perpendicular to veins, and either parallel or perpendicular to bedding. Thin sections were analyzed using conventional and scanning-electron microscopy (SEM). The SEM is an FEI Quanta 650 field-emission gun with backscattered electron (BSE) and energydispersive X-ray spectroscopy (EDS) detectors. All SEM operations were performed at $20 \mathrm{kV}$. EDS spectra were collected at $10 \mathrm{~mm}$ (2.5 inch) working distance. To quantify constituents of veins and host rocks, we point-counted co-located BSE and EDS images. Each point-count dataset consists of 300 counts made on a grid spacing near the average grain size. Organic matter and pore space are grouped into a single category for our point counts, because of our inability to reliably ascertain the distribution of methane or to distinguish epoxy, empty pores, and organic-matter-filled pores in our thin sections, which were carbon-coated for SEM.

We analyzed oxygen and carbon isotopes within vein and bulk-rock carbonates, and carbon isotopes within bituminous vein fill. Analyses of stable isotopes (carbon, oxygen) were performed at the Open University, Milton Keynes, UK. Calcite samples were powdered and washed in 10\% vol./vol. peroxide to devolatilize and oxidize sulfur (Chirita, 2004). Samples were measured using a ThermoFinnegan Delta V mass spectrometer. C- and O-isotope data are expressed relative to the Vienna PDB scale by reference to in-house calcite standards calibrated to NBS-19. External reproducibility was estimated from repeat analyses of individual samples as \pm 0.2 per mil (1 S.D.). 
225 Organic matter contained within bitumen veins was collected by gently scratching vein surfaces with a sterile needle. The accumulated residue was decarbonated by washing in $2 \mathrm{M} \mathrm{HCl}$, and subsequently rinsing in de-ionized water until neutral $\mathrm{pH}$ was reached. Enough dried powder to obtain $\sim 30 \mu \mathrm{g}$ of organic carbon for analysis was weighed into a tin capsule. The carbon isotope composition was analyzed using a Thermo Scientific Flash 2000 HT Elemental Analyser coupled to a Thermo Scientific MAT 253 mass spectrometer. $\delta^{13} \mathrm{C}$ values are expressed relative to VPDB after normalizing to certified standards (IAEA CH-6 sucrose and NIST 8573 L-glutamic acid) measured in the same analysis session. Reproducibility estimated from these standards was $< \pm 0.1 \%$ (1 S.D.).

Strontium isotopic analyses were performed at the University of Oxford. Carbonates were analyzed separately from the bulk rock by leaching in dilute $(0.5 \mathrm{M})$ acetic acid for $\sim 30$ minutes. The remainder of bulk rock samples were digested using concentrated $\mathrm{HF}, \mathrm{HCl}$, and $\mathrm{HNO}_{3}$ and analyzed separately. Strontium was collected using the ion exchange column method outlined by Charlier et al. (2006), and analyzed on a Nu Plasma MC-ICP-MS coupled to a desolvating nebuliser. Data were corrected for instrumental mass bias by sample-standard bracketing to NIST 987 (certified value 0.710255). Repeat analyses of NIST 987 during the course of this study gave an average value of $0.710271 \pm 0.000089$ $(n=60,2$ S.D. $)$.

RESULTS

Stratigraphic and regional fracture distribution

247 Regionally, the stratigraphic thickness of the Marcellus Formation is greatest toward the northeast (Figure 3A), consistent with the inferred deltaic depocenter interpreted by Lash and Engelder (2011). Observations of core photos from the regional database (Figure 3) show relatively high vein frequency in the northeast and southwest of the NE-SW trending core coverage area; vein frequency is lower toward the middle of the basin. Vein intensity also systematically decreases toward the 
foreland. On core photos, the frequency of faults decreases toward the east, and is broadly coincident with local minima in the thickness of the underlying Salina Formation salt. Layer-parallel veins filled dominantly or completely with pyrite are more common in the Lower Marcellus than in the Upper Marcellus, throughout the basin (Figure 3C).

\section{FMI observations}

An FMI log was interpreted from the wellbore from which Core A was retrieved (Figure 4). The log covers the "heel" through "toe" portions of a lateral well landed within the Lower Marcellus. Traces of fractures at high angle to bedding in FMI typically form sinusoids where the planar fractures intersect the circular wellbore (Figure 4A). Such fractures include conductive and resistive features, interpreted as partially or fully open and sealed fractures, respectively. Bedding is generally horizontal except at two intervals: bedding dips moderately toward NNW from 9400-9500 feet measured depth, and moderately toward SSE from 9600 to 9900 feet measured depth. Within these dipping intervals there is a greater frequency of non-vertical fractures having shear offset; where bedding is horizontal the vast majority of fractures are opening-mode and near vertical. This pattern is consistent with core observations listed below, considering that layer-parallel fractures are probably numerous but difficult to distinguish from bedding planes on FMI logs.

\section{Core-scale observations}

Veins in mudrock and limestone layers are dominantly calcite-filled, with subsidiary pyrite, barite, quartz, and dolomite (Table 1). Porosity is rare but locally present amid euhedral mineral-fill faces; no entirely porous fractures were encountered except for fragmented core pieces having no evidence of a geologic origin such as slickensides or bitumen. Veins in sandstone layers are generally filled with quartz cement, with relatively abundant pore space and only local carbonate fill (Figure 5). Macroscopic bitumen is present in $8 \%$ of fractures logged, all of which are vertical (Figure 6B, C). Bitumen veins are most common in Core $\mathrm{P}$, within the Utica shale. Bitumen is generally present near 
the middle of fractures that are lined with carbonate cements. This type of bitumen-calcite vein fill is common in some layers.

282

Vertical calcite veins may contain pyrite and trace quartz and barite, as well as bitumen. Layerparallel veins are generally monomineralic, with rare exceptions containing calcite with pyrite, associated with pyrite concretions.

Strike observations in Core F as well as FMI show two vertical fracture sets, which strike NNW and NE, roughly parallel and perpendicular to the closest fold axis (Figure 1). Of 127 vertical fractures for which strike was determined, 95 (75\%) strike NNW. Layer-parallel fractures are abundant. Twelve observed crosscutting and abutting relationships indicate an earlier timing of layer-parallel fractures, relative to vertical fractures. Intersections between the two vertical fracture sets are rare, but the two sets are observed to mutually crosscut. Macroscopic bitumen was locally observed in both sets (Figure 5, Table 1).

Opening-mode veins in the Upper and Lower Marcellus shales are generally isolated, with little branching or linking. In contrast, shear veins tend to link with nearby veins, in some cases forming interconnected networks of fracture segments. Below we describe crack-seal texture in veins, suggesting repeated opening and cementation during vein growth; this texture is most commonly observed using a microscope but is locally identifiable at the core scale. Veins in the Cherry Valley limestone contain almost exclusively calcite and more commonly display shear offset and branching, relative to mudrock-hosted veins.

High angle-to-bedding fractures, particularly the NNW-striking set, may have wispy tips; such fractures splay into multiple thin strands at their tips (Figure 6). The middle of the fracture (usually $>90 \%$ of the total trace) is discrete. Fractures having such wispy tips are more common in layers rich in carbonate material. 
Veins have a range of aspect ratios (height divided by aperture-Figure 7), and therefore a poor correlation between height and aperture. Bedding-parallel length is generally not measureable, owing to the geometry of the fracture-core intersection, except for some bedding parallel fractures for which both tips were intersected by the core. The lack of correlation between height and aperture may at least in part stem from the tendency for veins to splay into en échelon segments (Figure 6), such that the length of an individual vein is a subjective measurement.

Stylolites are abundant within the core, both layer-parallel (Figure 6) and layer-perpendicular (Figure 8). Both stylolite orientations are more common in carbonate-rich layers, such as the Cherry Valley limestone (Figure 8).

Shear veins and faults are present, including calcite-cemented breccia zones and uncemented surfaces with slip lineations, which are often parallel to bedding (Figure 8). In some cases vein opening appears to have been accommodated by slip along bedding planes (Figure 8C, D). Numerically, shear veins make up a small fraction of the entire vein population. A total of 21 cemented fractures were observed to have obvious shear displacement along the vein plane, of 285 total measured (7\%).

Pyrite is the second most abundant diagenetic mineral in mudrock beds, after calcite. Pyrite commonly forms nodules and fills veins, and, as described below, is a significant primary sedimentary constituent in black mudrock layers. Pyrite nodules may or may not displace host beds. Displacive pyrite forms shapes suggestive of a spectrum between ellipsoidal nodules to tabular, layer-parallel fractures (Figure 9). Pyrite may either displace host-rock or fill pore space. Non-displacive or partially-displacive pyrite forms a variety of irregularly shaped bodies, often associated with pyrite or calcite-filled fractures (Figure 9). Crosscutting and overgrowing relationships suggest that calcite typically post-dates pyrite, whether as a subsidiary cement in a growing concretion or as the primary filling cement in a later vein.

\section{Petrography}


337 The host-rock carbonate fraction in mudrock layers is dominantly microfossils and cements, composing typically near 10 but locally up to near $50 \%$ of the host rock (Figures $10 \mathrm{~A}, 10 \mathrm{~B}, 11$ ).

Dolomite in the host rock typically takes the form of dispersed rhombohedra, on the order of 5-50 $\mu \mathrm{m}$ in width. The non-carbonate fraction of these layers is dominantly illite and subsidiary chlorite, with silt-sized quartz and albite comprising generally less than $20 \%$ but up to roughly $30 \%$ of the host rock (Figure 11). Detrital quartz and albite grains are generally more common in the Upper Marcellus, whereas the Lower Marcellus is more clay-rich. Pyrite is a common cement, both as framboids and as microscopic euhedral crystals and macroscopic concretions. Organic matter/porosity, pyrite, quartz, and dolomite are present, in decreasing order of abundance, and generally with greater abundance in the host rocks than in the veins (Figure 11). Barite is less common than pyrite but also locally abundant, particularly within veins and concretions. Barite and calcite are the only constituents systematically more abundant in veins than in host rocks.

Limestone layers are interspersed through the mudrock formations. The Cherry Valley limestone is a thick and regionally correlable example. Host-rock carbonate in limestone layers comprises microfossils, macrofossils, and cement.

Cement within layer-parallel fractures in mudrock layers is generally fibrous and is devoid of bitumen or pore space (Figure 9). Such textures are consistent with antitaxial (center-outward) fracture growth matched by cement precipitation and lacking repeated cracking episodes (Bons and Montenari, 2005). Cement inside steeply dipping fractures may be fibrous but is more commonly blocky or elongateblocky (Bons et al., 2012), indicating competitive growth into void space. Cement crystals may be stretched (Bons et al., 2012) indicating repeated cracking and sealing of fractures (Figure 12C). Many stretched crystals also contain bands of fluid or host-rock inclusions, also consistent with repeated opening amid cement precipitation. 
Vertical calcite veins in carbonate-poor mudrock layers commonly have crenulated walls (Figure 13).

364 The crenulations are most apparent in cross section and are equally developed on NE and NNW striking veins. The fill of such fractures consists of micron-scale, equant blocks at roughly the same size-scale as the fracture-wall crenulations. Pyrite, barite, and quartz are common in such veins.

Veins that bear significant amounts of quartz, pyrite, and barite among calcite are commonly associated with macroscopic pyrite-barite concretions. As shown in Figure 14, the four minerals generally occur intergrown in patches, with both euhedral and smoothly curved anhedral surfaces present upon all phases.

SEM analysis of bitumen-bearing calcite veins generally reveals at least two phases of carbonate cement (Figure 15). An early phase lines fracture walls and may contain primary bitumen inclusions. This early phase also may contain dolomite, which has been partially recrystallized to calcite. Dolomite and recrystallized calcite locally have wall-parallel fluid inclusions and form as narrow rows of rhombohedra that span across fractures. A later phase of calcite cement is present within poorly aligned fractures inside the bitumen, near the middle of fractures. These poorly aligned cracks tend to mutually abut rather than crosscut one another.

Veins having significant amounts of quartz cement are only found within quartz-rich sandstone layers of the Oriskany Formation. Such quartz-bearing veins are also more porous than the calcite veins in the mudrock layers. This pore space is situated among pillar shaped "bridges" (Becker et al., 2010) of quartz cement that span across fractures (Figure 16B-E). Bridges contain trails of fracture-parallel, single-phase fluid inclusion assemblages, as well as crack-seal texture, visible in CL (Figure 16C, E). veins. 
391 Analysis of $\delta^{18} \mathrm{O}$ shows that host-rock carbonates of all samples range from $\sim-8$ to $-11 \%$ VPDB

392

393

394

395

396

397

398

399

400

401

402

403

404

405

406

407

408

409

410

411

412

413

414

415

416

(Figure 17, Table 2). Vein carbonate cements from the same samples are depleted by $\sim 1 \%$ relative to the host rock. Combining all data points, there is no statistically significant correlation between hostrock and vein $\delta^{18} \mathrm{O}$. However, subdividing vein-host-rock pairs by vein orientation (NNW strike, NE strike, layer-parallel) produces better-defined groups, having distinct oxygen isotopic compositions (Figure 17A), than does subdividing by host layer (Upper Marcellus, Lower Marcellus, Utica Formation-Figure 17B).

Observed $\delta^{13} \mathrm{C}$ in the host-rock carbonate of almost all samples ranges from $\sim+2$ to $-5 \%$ VPDB (Figure 17, Table 2). $\delta^{13} \mathrm{C}$ within the veins is roughly equal, or enriched up to $3 \%$, relative to the corresponding host-rock. There is one outlier to this trend (Core F, depth 5845.9 feet), which contains extensive carbonate cement having anomalously light $\delta^{13} \mathrm{C}$ in the host rock $(-14 \%)$ yet a typical vein composition $(-3 \%)$. In contrast with the oxygen results, there is a statistically significant correlation between $\delta^{13} \mathrm{C}$ in the host-rocks and veins, judged by the Pearson coefficient, including $(r=0.693)$ or omitting $(r=0.686)$ the outlier. In further contrast to the oxygen data, $\delta^{13} \mathrm{C}$ data for vein-host-rock pairs form more distinct groups when subdivided by host formations (Figure 17B) than by vein orientations (Figure 17A).

There is some variation in $\delta^{13} \mathrm{C}$ within veins. One layer-parallel fibrous vein, having an apparently antitaxial fill pattern, including a central medial zone and fibrous fill on either side, was sampled twenty times from wall to wall (Figure 18). The vein was preserved loose in the core box, so it is unclear which fibrous zone is upper and which is lower, so we call the fibrous zones "A" and "B." Fibrous zone A includes trace barite and quartz cement, forming fibers parallel to the calcite. Zone B contains only calcite. The host-rock $\delta^{13} \mathrm{C}$ measured is $-1.01 \%$. In fibrous zone $\mathrm{A}, \delta^{13} \mathrm{C}$ ranges from 0 to $-1 \%$; in fibrous zone $\mathrm{B}, \delta^{13} \mathrm{C}$ ranges from 2 to $4 \%$. 
417 Organic carbon in bitumen in veins ranges from -29 to -31\% VPDB - Figure 17D, Table 2).

418 Carbonate ${ }^{13} \mathrm{C}$ in bitumen veins is heavier, showing values near zero \%o, like those of the rest of the 419 carbonate.

421 Our preliminary results show that the ${ }^{87} \mathrm{Sr}^{186} \mathrm{Sr}$ compositions of rock components (Figure $17 \mathrm{C}$, Table 2), in increasing order (from least radiogenic to most radiogenic), is: host-rock carbonate, vein carbonate, residual host-rock (i.e., the non-carbonate portion of the host rock). The composition of global ${ }^{87} \mathrm{Sr}^{186} \mathrm{Sr}$ seawater for the mid Devonian depositional age of the mudrocks (Veizer et al., 1999) is lighter than any of these three components (Figure 17C).

\section{DISCUSSION}

Stresses during fracturing

There is ample evidence from previous studies that the stress field during veining was a function of tectonic loads plus increased fluid pressure resulting from catagenesis. Tectonic loads are evident from the regional-scale orientation of joints and veins, some of which are kinematically coherent with regional anticlines (Engelder and Whitaker, 2006; Wilkins et al., 2014). Fluid overpressures related to catagenesis are evident from horizontal fractures (Lash and Engelder, 2005), methane-saturated fluid inclusions (Evans et al., 2012), higher fracture frequency in more organic-rich horizons in otherwise analogous settings (Lash et al., 2004), and fracture propagation/arrest marks consistent with fluid pressure cycling (Lacazette and Engelder, 1992). Previous studies have also argued that vein formation occurred before and during peak burial, upon burial to depth sufficient for thermal gas generation (Evans, 1995; Evans et al., 2014).

Methane is generated in situ in organic rich shales such as the Marcellus and Utica shales, so no external fluid source is needed to supply the overpressure. Furthermore, shales have low natural permeability, relative to sandstones and limestones. Most veins have little present-day porosity, and 
have fill textures suggesting they were mostly or completely cemented while they opened, albeit most including microscopic, if not macroscopic, amounts of organic matter. As we discuss below, all the vein filling minerals are present within the host rock and were probably present within the original sediment. Therefore we can posit a default hypothesis that all the vein fill derives from local host rock in a closed system, amid little or no fluid advection.

450

451 It has been shown that the mechanical properties of the beds exert a control on the vein distribution, 452 with relatively strong sandstones and limestones acting as struts within relatively compliant shales 453 (Evans et al., 2012). Wilkins et al. (2014) found the greatest fracture intensity associated with slip surfaces developed where mechanical contrasts are highest, such as at the upper and lower contacts of the Cherry Valley limestone and of cm-scale limestone nodules. We note this type of behavior in the present study area, as stiff filled veins and nodules tended to reactivate, in opening mode (Figure 12C) and in shear (Figure 9). We note that most of the rare fractures showing evidence for shear have small offset (cm-scale or less) and likely do not cross multiple formations.

\section{Host composition prior to fracturing}

Abundant skeletal calcite grains and detrital quartz and feldspar grains suggest that those minerals were major components of the original sediment. The platy appearance of clay flakes in SEM is consistent with a detrital origin, not authigenic (Welton, 2003). The same interpretation was made for a detrital illite source in Late Devonian black shales in western New York (Lash, 2006).

Dolomite rhombohedra in the host rock may be detrital or authigenic. If authigenic, the size range of the rhombohedra is similar to that observed in modern deep sea sediments (Lumsden, 1988). We see no evidence for dolomite as a pore-filling, nodular, or displacive cement. We therefore interpret that dolomite was present within the host rock before fracturing initiated. 
472 The presence of framboidal pyrite and nodular pyrite, calcite, and barite, around which the host

473 sediment is variably compacted, demonstrates that these minerals began precipitating early. Early

474 barite nodules were observed in outcrops of the Appalachian Basin by Lash and Blood (2014) and

475 interpreted as microscopic organic barite that was dissolved and reprecipitated near the sulfate-

476 methane transition zone; i.e., during early burial.

477

478

479

480

481

482

483

484

485

486

487

488

489

490

491

492

493

494

495

496

497

498

499

Sequence of vein cements

In nearly all veins the fill texture indicates that cement precipitation was synkinematic (during opening). These textures include fibrous and stretched-crystal morphologies (Figure 12), interpreted to fill ephemeral pore space in fractures whose opening rate was slower than, or close to, the potential cement precipitation rate (Bons et al., 2012). Early cement phases that form bridges at high angle to fracture walls (e.g., dolomite in Figure 15B, quartz in Figure 16) are also likely synkinematic, tracking fracture opening in isolated deposits where cement precipitation was locally faster, perhaps due to substrate effects (Lander and Laubach, 2015). Lastly, the wispy tips of many veins (Figure 6) appear to form during opening and because the tips of veins open more slowly than the rest of the vein. If such veins are height-restricted during growth, such that the tips remain in one place, then the cementation rate may be fast enough to repeatedly re-seal the tips, but not the rest of the vein. Later widening of the vein would then require re-cracking only at the tip, producing local branching at the tips of otherwise discrete veins (Caputo and Hancock, 1999; Hooker et al., 2014). The greater abundance of wispy veins within carbonate-rich layers also supports the interpretation that fast cementation rates, owing to abundant carbonate source-material and/or substrates, resulted in fast sealing and delocalization of progressive fracture opening increments, effectively modifying the fracture pattern (Hooker and Katz, 2015).

Calcite is the most abundant vein-filling mineral; it is present in significant amounts in all mudrockhosted veins except some pyrite veins (Figure 9). Calcite appears to have precipitated within most veins throughout their opening, based on abundant antitaxial-fibrous and other filling textures 
500 (Figures 12,13) that seal many veins. Pyrite is the second most common vein-filling mineral, and is 501 abundant particularly in veins hosted within early pyrite nodules (Figure 9). Many such veins show 502 evidence of compaction, suggesting pyrite and calcite both fill early veins. Dolomite is locally present 503 as an early (Figure 15) and a late (Figure 14) cement.

504

Barite appears as a late fracture filling phase, near the centers of syntaxial veins (Figure 14), consistent with interpretations by Evans (1994). Therefore barite likely formed as an early nodular cement, in accordance with Lash and Blood (2014), and may have been remobilized into fractures relatively late (Evans, 1994), at elevated temperature, as further discussed below. Barite apparently co-precipitated with quartz, pyrite, and calcite, as indicated by mutually interlocking euhedral faces.

511 Based on these observations, we present a mineral paragenetic sequence for the shale layers (Figure 19). Each mineral is present in each vein orientation identified. Therefore the only constraints we have on the relative timing of veins are (i) the early timing of irregularly-shaped pyrite-calcite concretions, based on differentially compacted laminae (Figure 9), and (ii) the general tendency for beddingparallel veins to predate bedding-perpendicular veins, based on crosscutting relationships.

Sources of vein fill

Most components of mudrock-hosted vein fill are present, in systematically greater abundance, within their host rocks (Figure 11). A simple interpretation is that most components are sourced locally, and were fed into veins via pressure solution-reprecipitation. This process was a major deformation mechanism during the Alleghanian orogeny, taking the form of stylolites oriented parallel to regional fold axes (Engelder, 1979). Calcium carbonate is the most pressure-soluble common component of the host rock, which explains its preferential mobilization into most veins, compared to that of organic matter, pyrite, quartz, and dolomite. The exceptions to this pattern include barite in veins in general, as well as pyrite and bitumen in some examples. In this section we focus on these exceptions, whose 
greater abundance in the veins than in the host rocks requires some explanation, if the vein fill is locally sourced.

Barite is present in the host rocks and so might have found its way into veins via pressure solutionreprecipitation. However, barite has notably low solubility, which reaches a maximum range around 0.1 to $1 \mathrm{mmol} / \mathrm{kg}$ near $100-150^{\circ} \mathrm{C}$, depending on pressure and salinity (Blount, 1977). This temperature range is close to the maximum likely experienced by these rocks, and so could explain mobilization of barite into veins near maximum burial. But at that temperature range quartz has similar solubility (Siever, 1962; Shock et al., 1989), and is much more abundant in the host rock, so it is difficult to explain how barite crystals in the host rock would become preferentially dissolved and mobilized into veins, while quartz remained in the host rock. Barite solubility can further increase upon removal of sulfate during sulfate reduction (Torres et al., 1996), which may have been thermally activated at depth (Machel et al., 1995), but this mechanism does not explain re-precipitation into veins.

One alternative possibility is that the fractures conducted an external fluid into the rock, resulting in supersaturation with respect to barite. Such was the interpretation of barite cement in sandstones overlying evaporites, interpreted to be a source of sulfate (Breit et al., 1990). Another possibility, consistent with a closed fluid system, is that $\mathrm{Ba}^{2+}$ may have limited barite precipitation. Barium is common in organic matter and as a substitute for potassium (Griffith and Paytan, 2012); in the observed rocks, barite is commonly found associated with organic matter (Figures 10E, 15D) and in the interstices of potassic clays (Figure 10D). Therefore it may be that upon sufficient thermal exposure, barium was liberated from these host-rock constituents. These two potential barite saturation processes are not mutually exclusive.

The interpretation that most of the vein fills are sourced locally also accounts for the general increase in less soluble minerals in late fracture assemblages - i.e., the latest cement deposits within vertical veins - and within crenulated veins (Figures 13, 14). If the veins formed prior to or during maximum 
burial — consistent with previous work (Evans et al., 2014), with their inferred solution-precipitation filling mechanism, and with their orientation with respect to folds - then we would expect increasing abundance of quartz, pyrite, and barite within veins over time. An exception to this observation is the abundant pyrite in some early, layer-parallel veins (Figure 9). We note again the variety of morphologies of pyrite-calcite nodules, many of which form irregular fractures (Figure 9). It is possible that early calcite and pyrite formed veins amid overpressures related to disequilibrium compaction (e.g., Hillier and Cosgrove, 2002). Early pyrite veins associated with nodules need not have dissolved previously; rather, early pyrite vein fill likely precipitated directly from solution in the formation water, in response to bacterial sulfate reduction (Machel et al., 1995). These early minerals would be susceptible to later remobilization, just as any other host-rock components.

Organic matter is common throughout the host mudrocks and relatively enriched within some veins (Figures 6B, 10E, 12C, 15). Within such veins the organic matter is pyrobitumen, precluding the use of most petrographic techniques to investigate its origin, but not inconsistent with a local source. We discuss the mobilization of organic matter into mineral veins below, in our discussion of fracture mechanisms.

Also consistent with a local source of cements, rare vein-filling cements such as sphalerite (Figure 13) appear exclusively in the vicinity of rare host-rock components of the same minerals. The short transport distances suggest minimal advection of fluid during fracturing; rather, the veins were fed by diffusion of material through static fluids.

In sandstones, quartz cement dominates (Figures 5,16). Moreover, this lithology is the only one present that contains little carbonate in the host. The greater porosity in quartz bearing fractures is likely a function of very slow quartz precipitation rates on euhedral faces (Lander et al., 2008; Lander and Laubach, 2015). The absence of carbonate in porous fractures in sandstone layers could reflect the low matrix permeability of the shale versus a higher permeability of the sandstone, such that any 
diffusion of carbonate ions into the sandstone was soon removed from the system by advective flow in the sandstone.

In summary, with the exception of some early veins associated with pyrite nodules, and possibly of trace barite, we interpret that the vein filling material was sourced from the nearby host rock, and fed into the veins via pressure-enhanced dissolution-reprecipitation. This interpretation is based on the abundance of vein-filling minerals in the host rock, the spatial coincidence of minerals in the fractures and host rocks, and the increasing abundance of less-soluble minerals within veins over time.

\section{Oxygen isotopes}

We suggested above that barite and probably most cement entered fractures via dissolutionreprecipitation from the host rock. The similarity in isotopic composition between the host-rock carbonate and the vein carbonate, for each element analyzed (Figure 17), is consistent with the same 'closed-system' mechanism as a source for the vein calcite. In principle we might expect an identical oxygen composition between the host-rock and vein carbonates, but the veins are systematically depleted by roughly $1 \%$ (Figure 17B; Table 2).

The carbonate fraction of the host rock is composed of seafloor carbonates (fossil tests) and cements. Oxygen in bulk host-rock carbonates (-8 to $-10 \%$ VPDB) is depleted relative to that expected for Mid-Devonian seafloor carbonates (-4 to -7\%o-Veizer et al., 1999). This raises an important question: can closed-system diagenesis explain the 1-6\% depletion of the host-rock carbonates, and the further $\sim 1 \%$ depletion of the vein cement?

Egeberg and Saigal (1991) and Maliva (1991) modeled North Sea chalks having depleted oxygen isotopic compositions by a combination of calcite recrystallization, precipitation, and increasing temperature within a hydraulically closed system, allowing only for water expulsion during burial compaction. We ignore this expulsion, because in the samples we observed, only trace amounts of 
calcite precipitated before the end of mechanical compaction, within some pyrite-rich nodules.

Otherwise we follow the approach of Egeberg and Saigal (1991) in assuming that calcite cement is sourced entirely from dissolution and reprecipitation of extant calcite, which is ultimately entirely derived from seafloor carbonates (Figure 20). The fluid is entirely connate seawater.

The interstitial fluids for seawater in equilibrium with seafloor carbonates would initially be on the order of -30 to $-40 \%$ VPDB. The isotopic composition of the formation water could be substantially modified by exchange with the oxygen within the silicates of the host sediment, particularly the clay (Yeh and Savin, 1977). For present purposes we ignore water from the dehydration of smectite to illite because, as stated above, we interpret the illite to be detrital and not authigenic. The formation water will also exchange oxygen with the albite and quartz. The effects of this exchange would likely be negligible compared to that of the water and carbonate, because the silicate minerals are less soluble than the carbonate, and because the silicate oxygen composition is likely an intermediate between the carbonate and the water (Yeh and Savin, 1977).

A numerical simulation of closed-system oxygen exchange between carbonate and water is run in time-steps; in each time step a given volume of calcium carbonate is dissolved from the host-rock and added to the water. In each time step, the same volume of calcium carbonate is precipitated, either into the host rock or into veins. User inputs include the initial isotopic compositions of the water and host-rock carbonate; the temperature, including any optional temperature change per time-step; the volumetric ratio of water to carbonate; and the portion of carbonate dissolved and precipitated per time-step, expressed as a fraction of the water portion.

We calculate the ${ }^{18} \mathrm{O}:{ }^{16} \mathrm{O}$ ratio of the formation water $\left(\mathrm{R}_{\mathrm{W}}\right)$ at a given time step $\mathrm{t}_{1}$ based on the previous time step $\mathrm{t}_{0}$ as

$$
\mathrm{R}_{\mathrm{W} 1}=\mathrm{R}_{\mathrm{W} 0}-(\mathrm{MDA}) \times\left(\mathrm{R}_{\mathrm{P}}+\mathrm{R}_{\mathrm{H}}\left(1-\mathrm{F}_{0}\right)+\mathrm{R}_{\mathrm{F}} \mathrm{F}_{0}\right)
$$


656

657

where $M$ is the volumetric carbonate:water ratio present; $D$ is the rate of carbonate dissolution, which is assumed to be the same as the rate of reprecipitation; $A$ is 1.566 , the volumetric ratio of oxygen atoms in calcite to water; $R_{P}, R_{H}$, and $R_{F}$ are the ${ }^{18} \mathrm{O}:{ }^{16} \mathrm{O}$ ratios of the carbonate precipitate, host-rock portion, and fracture portion, respectively; and $F$ is the portion of the total carbonate volume that is currently within fractures. We assume that dissolution affects all carbonate in the host rock uniformly, including reprecipitated carbonate. We calculate the instantaneous $R_{P}$ using the ${ }^{18} \mathrm{O}$ fractionation factor between calcite and water, $\alpha(\mathrm{T})$, according to the relationship experimentally derived by Kim and O’Neil (1997). Assuming proportional dissolution from host rock and veins, the bulk composition of the calcite within the host rock can then be estimated as

and that of the veins as

$$
\mathrm{R}_{\mathrm{F} 1}=\left[\mathrm{R}_{\mathrm{F} 0} \mathrm{~F}_{0}(1-\mathrm{D})+\mathrm{R}_{\mathrm{P}} \mathrm{F}_{1} \mathrm{D}\right] /\left[\mathrm{F}_{0}(1-\mathrm{D})+\mathrm{F}_{1} \mathrm{D}\right]
$$

To estimate the isotopic composition of vein cements, the user assigns an interval over which fractures open, at the same time assigning a temperature of fracture opening.

We begin by assuming that vein opening occurs amid increasing temperature, based on the mineral paragenetic sequence observed as well as previous studies of vein fluid inclusions coupled with burial models (Evans, 1995; Pommer et al., 2013; Evans et al., 2014; Wilkins et al., 2014). We therefore begin the simulation at shallow burial $\left(\sim 50^{\circ} \mathrm{C}\right)$ and increase temperature steadily to the maximum observed regional temperatures $\left(200^{\circ} \mathrm{C}\right.$ for the Marcellus Formation-Wilkins et al., 2014), initiating fracture opening at $180^{\circ} \mathrm{C}$. We then run the model through an uplift phase to a current temperature of $60^{\circ} \mathrm{C}$ at the end. 
665 For the shales in question, total porosity is on the order of $2 \%$; we assume a $100 \%$ water saturation,

666 pre-catagenesis. In black shale layers, the host-rock carbonate fraction ranges widely; most samples

667 have $<10 \%$ but many have close to $50 \%$. Therefore we use a default value of $M=5$ and use $M=1$

668 and $M=25$ for sensitivity analysis. Finally, we need to estimate the volumes of host-rock carbonate

669 that have been precipitated into veins. We can estimate the total fraction of the rock now represented

670 by veins using the best-fit relationship shown in Figure 7 to derive a length for each aperture

671 measurement, and calculating a core-face area for each fracture by representing it as an ellipse. The

672 areal fraction of the core faces observed representing veins is estimated as $0.1 \%$. Neglecting the part

673 of the vein fill that is not carbonate, and for a carbonate rock fraction of $10 \%$, this corresponds to $1 \%$

674 of the total carbonate now in veins; for a $50 \%$ carbonate rock fraction, $0.2 \%$ is now in veins.

675 Therefore we vary the precipitation rate $D$ and initiate and end fracture opening in the model such that

676 the final cement precipitation equivalent to 0.2 to $1 \%$ of the total carbonate volume is precipitated into

677 fractures.

678

679 Using these estimates we plot a range of modeled isotopic compositions of host-rock and vein

680 carbonates, at the present day and depth, in Figure 21. Modeling diagenesis and fracture opening amid

681 steadily rising temperature, the total volume of cement reprecipitated (controlled by the precipitation

682 rate) is the dominant control on the isotopic compositions (Figure 21). With greater volume of the

683

total carbonate dissolved and reprecipitated, the composition of the veins asymptotically approaches that of the host carbonate. The compositions merge more quickly for greater carbonate:water ratio. Depending on this ratio, the model predicts a difference between the oxygen composition of the vein and host-rock, $\Delta^{18} \mathrm{O}(\mathrm{V}-\mathrm{HR})$, of $1 \pm 0.61 \%$ for between 1 and 4 total volumes of cement reprecipitated. Interestingly, the observed $\delta^{18} \mathrm{O}(\%)$ values were most closely returned using $1<M<5$, coinciding with our best estimate of the carbonate:water ratio in mudrocks. We thus note an internal consistency to our model. However, the $\delta^{18} \mathrm{O}(\%)$ values vary approximately linearly with the chosen initial values for the carbonate and water. We have little constraint on these values, other than the global values reviewed by Veizer et al. (1999). 
693 Next we relaxed our assumption that the veins formed before or during maximum burial. We

694 performed the same simulation but initiated fracture opening at $180^{\circ} \mathrm{C}$, after peak burial—i.e., during 695 exhumation (Figure 21). In all cases, $\Delta^{18} \mathrm{O}(\mathrm{V}-\mathrm{HR})$ homogenizes to the host-rock value before three 696 carbonate volumes have been reprecipitated. For $M=25, \Delta^{18} \mathrm{O}(\mathrm{V}-\mathrm{HR})$ is positive throughout the 697 simulation. The same result held upon decreasing the water content, by increasing $M$ from 1 to 10 over maximum burial and uplift, to incorporate the effect of dehydrating the host rock during catagenesis.

In the above simulations we assumed continued isotopic exchange after fracturing, which homogenizes the compositions of the vein and host-rock carbonates over time. In reality there is likely a dramatic decrease in the rate of isotopic exchange, because pressure solution-reprecipitation was greatest during the Alleghanian orogeny (Engelder, 1979). As well, the coarser crystal size of the veins versus the host-rock carbonates gives the veins a lower surface/volume, which would tend to minimize isotopic exchange. As we discuss below, the trends in Figure 18B may reflect postfracturing isotopic exchange that is grain-size dependent. To account for reduced isotopic exchange upon cessation of fracturing, we re-plotted the instantaneous $\Delta^{18} \mathrm{O}(\mathrm{V}-\mathrm{HR})$, simulating an end-member scenario in which isotopic exchange entirely stopped once fracturing ceased (Figure 21).

710

The observed isotopic compositions are returned over a much wider range of model-space if fracturing during prograde burial is assumed, especially if the post-veining water-calcite exchange was an intermediate between our two end-member scenarios (i.e., reduced, but not zero-Figure 21). As well, fracturing during prograde burial is supported by the least-soluble minerals generally forming as the latest filling phases within veins; such minerals should be mobilized under the highest temperatures. Lastly, the prograde-burial assumption is consistent with previous studies documenting progressively high-temperature fluid inclusions in calcite veins (Evans et al., 2014).

719 Finally we note that ${ }^{18} \mathrm{O}$ within veins does not significantly covary with ${ }^{18} \mathrm{O}$ within host rocks (Figure 17). This lack of covariance would be expected if vein timing and temperature exerted a significant 
control on composition, diminishing the effect of the local host-rock carbonate composition.

Moreover, $\Delta^{18} \mathrm{O}(\mathrm{V}-\mathrm{HR})$ varies somewhat by vein orientation, with NE-striking, layer-parallel, and bitumen-bearing (strike unknown) veins more depleted than NNW-striking veins. Our model produces counterbalancing effects of vein timing on isotopic composition, because early veins formed at lower temperatures, when temperature-dependent fractionation was less significant, but also when water-rock interaction had less time to homogenize the carbonates. The former effect decreases $\Delta^{18} \mathrm{O}(\mathrm{V}-\mathrm{HR})$ and the latter increases it. A more detailed modeling of these effects would benefit from more extensive sampling and better timing relationships than we have at hand; for now we simply note that the grouping of oxygen isotopic patterns by set likely reflects the effects of temperature, in combination with host-rock compositions, on vein compositions.

\section{Carbon isotopes}

Vein cements are not appreciably depleted in ${ }^{13} \mathrm{C}$ (Figure 17). Relative to host-rock carbonate, vein carbon is similar in composition or slightly enriched, with overall values for both ranging from -5 to $+2 \%$ VPDB, aside from the single host-rock outlier. This outlier contains significant authigenic cement within the host, whose depleted carbonate composition could be explained by cementation as a byproduct of sulfate reduction (Machel et al., 1995).

The initial sediment likely included two major, isotopically distinct pools of carbon. These are the carbonates, which should have had initial $\delta^{13} \mathrm{C}$ compositions of 0 to $+2 \%$ VPDB (Veizer et al., 1999), and the organic carbon, which would have been significantly lighter, owing to preferential uptake of light carbon by organic processes (e.g., Galimov, 2006). The measured carbon compositions of bitumen in veins (Figure 17D) range from -29 to $-31 \%$; the original bulk organic carbon was likely even lighter, because catagenesis preferentially moves light carbon into the gas phase (e.g., Berner et al., 1992). 
Vein $\delta^{13} \mathrm{C}$ values near zero \%o VPDB, and near to and covarying with those of host-rock carbonates, support the host-rock carbonates as a source for the vein material, as opposed to the organic material. The carbon compositions therefore also support the dissolution-reprecipitation mechanism discussed above, as opposed to vein carbonate sourced from organic carbon. We note especially a distinct subpopulation of $\delta^{13} \mathrm{C}$ data for the sub-salt Utica Formation veins (Figure 17).

753

Lacking a carbon atom in water, and in the absence of carbon dioxide, we might expect conservation of carbon between the host-rock and vein carbonates, if indeed the veins were fed by dissolutionreprecipitation of host-rock carbonates (Hudson, 1975). Abundant light, organic carbon in the host material could readily explain depletion of carbon in carbonate cements, but the observed enrichment is more puzzling.

759

Calcite veins with isotopically heavy carbon in coal beds have been attributed to secondary biogenic processes - acetate fermentation and carbon dioxide reduction — which fractionate carbon to produce light methane and heavy carbon dioxide and carbonates (McLaughlin et al., 2011). However, no such biogenic processes seem plausible for deeply buried Devonian shales at temperatures higher than $\sim 70^{\circ} \mathrm{C}$ (Machel et al., 1995). Moreover, the organic-carbon pool from which that carbon originates would be significantly depleted in carbon, considering that even the residual pyrobitumen observed in veins here is much lighter than the carbonate. Calcite veins in coal beds can be significantly enriched in heavy carbon, but this enrichment is commonly quite variable, and in some cases is relative to a baseline that is typical of (depleted) organic carbon (Gould and Smith, 1979; Pitman et al., 2003; Pashin et al., 2014). carbon, achieved by exchange with nearby organic carbon. If a vein forms with a carbon composition identical to that of the host rock carbonate, then post-veining incorporation of depleted organic carbon

774 into the carbonate in the host-rock, possibly catalyzed by minor organic-derived carbon dioxide, might cause the observed discrepancies. Depleted organic carbon would also mix with any extant 
780

781

veins, but it may be that the larger crystal size within veins would help to preserve the original, heavier carbon composition, whereas the microfossils and other fine-grained carbonate fragments within the host rock could be more thoroughly exchanged with the depleted carbon from the organic matter.

This explanation is also consistent with the gradual depletion of vein carbon towards the vein wall of fibrous zone B in the vein in Figure 18. Fibrous zone A has a carbon composition close to that of the host-rock; carbon is enriched up to 5\% in fibrous zone B. The calcite within zone A is intergrown with barite and quartz cement; zone B contains only calcite. Thus both the isotopic compositions and mineral assemblages support a relatively early timing for zone B and a late timing for zone A. During vein opening and cementation, both fibrous zones had the same ${ }^{13} \mathrm{C}$ compositions as the host-rock carbonate. Because zone A precipitated later its ${ }^{13} \mathrm{C}$ reflects that of the host-rock after significant exchange with organic material. The cement in zone B preserves the early, heavier ${ }^{13} \mathrm{C}$ of the hostrock carbonate before exchange with organic material. Note that we see also a small enrichment of ${ }^{18} \mathrm{O}$ over the same region of the vein; this enrichment could be explained by the same exchange process with the surrounding fluid, with oxygen producing a much subtler effect owing to the previous near-equilibration of oxygen, modeled above, versus the highly contrasting compositions of the vein carbonate and surrounding organic carbonate.

Likewise, the carbon compositions of some of the the host-rock carbonates are mildly depleted relative to the expected composition of normal seawater-derived carbonates for the Middle Devonian (Veizer et al., 1999; Figure 17). This depletion is consistent with the host-rock carbonate being depleted by uptake of organic carbon since burial. The factors that would likely increase the degree of carbonate depletion by organic carbon are smaller carbonate grain size, greater initial difference in isotopic composition between carbonates and organic carbon, and integrated time and temperature. Future work could model these cumulative effects and potentially use ${ }^{13} \mathrm{C}$ compositions to constrain vein timing with respect to host-rock maturity. 
Results from strontium isotopic analysis suggests that strontium in calcite veins could be sourced

from the host rock, as vein ${ }^{87} \mathrm{Sr} /{ }^{86} \mathrm{Sr}$ is the same as host-rock carbonate ${ }^{87} \mathrm{Sr} /{ }^{86} \mathrm{Sr}$ or slightly higher, but amounts of strontium in the rubidium-rich detrital silicate fraction of the host were incorporated into the veins during vein opening and sealing. There is no direct evidence from strontium compositions for external fluids having reached the veins, although if external fluids are responsible for barite in

812 fractures, then such a fluid may also have affected strontium compositions in carbonates.

In principle we might expect the host-rock carbonate to become more enriched in ${ }^{87} \mathrm{Sr}$ in the same way it became lighter in ${ }^{13} \mathrm{C}$, because of exchange with non-carbonate host-rock components. We can speculate that the low solubility of silicates and high ionic bond strength of the $\mathrm{Ca}^{2+}\left(\mathrm{Sr}^{2+}\right)$ cations in the calcite lattice minimized post-fracturing isotopic exchange.

\section{Vein bitumen}

Bitumen is locally present in veins, both as microscopic inclusions within carbonate crystals and as massive accumulations between carbonate cement deposits (Figure 15). Liquid hydrocarbon inclusions within synkinematic dolomite bridges (Figure 15B) suggest that carbonate cements were deposited despite presence of mobile hydrocarbons in fractures. Macroscopic bitumen deposits within wispy-tipped fractures (Figure 6C) are further evidence that organic material did not preclude cementation, although the bitumen may have entered the fracture after the wispy tips formed.

The relatively early cement within bitumen veins consists of wall-lining, partially recrystallized dolomite. This early phase appears to have precipitated during the opening of bitumen veins, based on wall-parallel fluid inclusion trails. The later calcite micro-veins are generally surrounded by bitumen and their polygonal morphology resembles cracks or faults often attributed to desiccation of mud 
832 (Kindle, 1917), cooling of basalt (Aydin and DeGraff, 1988), or diagenetic volume loss of fine-

833 grained passive-margin sequences (Cartwright, 2011). Thus we interpret that these late calcite-filled

834 fractures formed while the originally liquid bitumen within the veins was heated and transformed to

835 pyrobitumen. The loss of bulk volume of the bitumen during this process, amid the relatively fixed

836 internal volume of the vein, resulted in the opening of cracks to fill the resulting void space. Calcite

837 then filled these cracks, suggesting an aqueous fluid was present. Perhaps this fluid was water

838 expelled from the bitumen, but our isotopic sampling techniques are not precise enough to isolate

839 these smaller cracks to test this idea.

840

841 Highly isotopically depleted carbon is expected and found within bitumen, reflecting its organic

842 nature. The presence of less isotopically depleted carbonate cements lining the walls of bitumen veins

843 is consistent with the presence of an aqueous phase and an inorganic source of carbonate cements in

844 bitumen veins.

845

846

Timing and origin of the calcite veins

847

848

The present paragenetic evidence and oxygen-isotopic modeling supports previous evidence that the calcite veins in the Appalachian plateau formed during prograde burial, and fracturing was minimal during subsequent exhumation. This pattern is observed across the Appalachian plateau-above the Salina Formation décollement in northeastern Pennsylvania as well as beneath the décollement in western Pennsylvania. In the Valley and Ridge province there is evidence for late-stage mineralized

853 fracturing, under lower fluid pressure and amid less saline water (Evans et al., 2012, 2014). This late fracturing may be related to meteoric invasion or the late fold tightening and cross-stratal faulting that also locally opened the fluid system. But even in the absence of such processes toward the foreland, it is curious why fracturing should have ceased at the onset of exhumation. The question remains: did fracturing cease, or only cementation? 
In principle we must distinguish between tectonic uplift of anticlines relative to synclines versus postorogenic isostatic rebound. The latter almost certainly dominated exhumation in the Appalachian plateau. Seismic surveys (Mount, 2014) and the Core Lab well database indicate less than $1 \mathrm{~km}(3,000$ feet) of structural relief in the vicinity of Tioga County, so $4 \mathrm{~km}$ (13,000 feet) of uplift is mostly attributable to post-orogenic exhumation.

Layer-parallel fractures are systematically crosscut by vertical fractures in the observed cores. As mentioned above, some layer-parallel fractures may significantly pre-date orogenesis, but we can posit that many layer-parallel fractures coincided with the initiation of a thrusting regime (minimum principle compressive stress, $\sigma_{3}$, vertical) that eventually caused the basin-scale folding. The NEstriking fractures may pre- or syn-date the folds. The NNW-striking fractures appear to have formed during folding, possibly by oroclinal bending (Marshak, 1988; Wilkins et al., 2014). Therefore with progressive folding, local $\sigma_{3}$ may have been horizontal and parallel or perpendicular to fold axes.

872 (Also, of course, folding can rotate extant fractures from their propagation-orientation, which appears to be the case where our FMI log sampled dipping beds (Figure 4E). However, our core sampling of flat-lying beds near anticlinal crests generally precludes this potential complication.) Mutual crosscutting between the two vertical fracture sets suggests that $\sigma_{3}$ likely alternated over time at any given position. The common presence of combined opening and shear displacement along fractures is also consistent with changing stress states over time, which may potentially preserve or enhance natural fracture permeability (Bisdom et al., 2016).

The above factors likely dominated the stress state near maximum burial, maximum temperature, and likely near maximum net gas production. At this time, some combination of crustal stretching and catagenetic fluid pressure drove the rocks to failure. How might the stress field have evolved subsequently? Factors that would tend to promote fracturing include reduction in remote compression - due to both exhumation and the cessation of Alleghanian compressive tectonics — as well as thermal contraction (English, 2012). Factors inhibiting fracturing include the cessation of the crustal stretching related to the Alleghanian orogeny, if that is what drove vertical fractures open, as 
well as the end of catagenesis. Catagenesis likely stopped upon exhumation and concomitant cooling, because the time-temperature integral upon which the maturation of hydrocarbons depends is usually limited by temperature, given geologic time scales (e.g., Schobert, 1990). The fluid pressure may have declined, but slowly, given the low permeability of these rocks and the fact that gas saturation is still high enough for economic flow rates.

If fracturing ceased at maximum burial, then we would infer that the halting of crustal stretching and catagenesis, and thus outer-arc folding and fluid overpressuring, outweighed the general decompression and cooling-contraction that accompanied exhumation. Alternatively, it may be that late-stage deformation was concentrated in the fold limbs, such that the hinges examined were relatively unstressed at the onset of exhumation. This idea is consistent with folds developing as kink bands, in which case fold tightening is accomplished by bed-parallel slip within fold limbs (Faill, 1973). These observed changes in fracture orientation and offset mode in fold limbs (Figure 4E) support this mechanism in the current study area, although we have no direct evidence of the timing of these fold-hinge veins. In general, because our data do not sample limbs, we may systematically underrepresent late-stage deformation.

It is also possible that gas saturation of the pore space displaced water and therefore inhibited the dissolution and reprecipitation of minerals, suppressing fracturing or erasing its geological evidence. It has been proposed that methane in fractures can prevent pressure solution along joint faces and suppress cement precipitation in fractures, based on unhealed NE-striking joints interpreted to have reactivated during, and therefore predate, folding and layer-parallel pressure solution (Engelder and Whitaker, 2006; Engelder et al., 2009). This interpretation is at odds with the common presence of methane and liquid hydrocarbon inclusions within calcite veins (Evans, 1994; Evans et al., 2014). Moreover, there is carbonate cement within bitumen veins, the later phase of which appears to postdate bitumen. Finally, we do not observe any gradual reduction in mineral content within hightemperature assemblages, nor any slightly cemented fractures in general, which would be expected if progressive heating and catagenesis gradually displaced water and thus inhibited cement precipitation. 
916 Evans et al. (2014) interpreted barren NE-striking fractures to be late folding-related fractures, on the

917 basis that pre-folding fractures should not have escaped the regional pressure solution and filling that

918 affected other fracture sets. In that case it was argued that deep seated NE-striking fractures could

919 escape mineralization because stable, equilibrated fluid conditions held post-folding (Evans et al.,

920 2014). We might go a step further to say it is difficult to imagine an aqueous solution remaining in

921 equilibrium, to such an extent that it leaves evidence of neither carbonate solution nor precipitation,

922 since the Alleghanian orogeny. If nothing else, the decrease in temperature alone should have led an

923 initially equilibrated fluid to undersaturation and dissolved carbonates over that time. It may therefore

924 be that both a syn-orogenic or later timing and a pure methane composition were needed to preserve

925 the pristine joint faces. Nevertheless, the field evidence that such barren joints pre-date the folding is

926 compelling, and so the conundrum of pristine joint preservation remains unsolved. Nevertheless, we

927 prefer the interpretation that fracturing — not just fracture infilling — ceased after maximum burial, for

928 the reasons outlined above.

929

\section{CONCLUSIONS}

931

932 Calcite veins in the Marcellus Formation and the Utica Formation in the Appalachian plateau formed in a generally closed fluid system, with filling minerals supplied by dissolution-reprecipitation of local host-rock components. This conclusion is supported by the presence of each major vein constituent within its host-rock layer; the increasing abundance of less soluble minerals with progressive time, inferred to reflect increasing temperature; the absence of carbonate cements within nearby sandstones; and the similar isotopic compositions of calcite within the veins and the host rock. Barite is the only common low-solubility mineral that is more abundant in the veins than in the host rock. Barite either formed via introduction of external fluids, such as sulfate-rich brines from the Silurian salts, or via liberation of barium from potassic clays or organic matter in the host rock. Small

941 but systematic depletion of ${ }^{18} \mathrm{O}$ within veins is consistent with closed-system precipitation under 942 increasing temperature. Enrichment of ${ }^{13} \mathrm{C}$ within veins can be explained by calcite-grain-size 
dependent exchange of carbon between organic material and calcite. Multiple phases of carbonate

944 cements are present in bitumen-bearing veins, including a late phase filling fractures within bitumen;

945 such fractures are interpreted to have formed during volumetric contraction during progressive

946 catagenesis. Hydrocarbons did not suppress cement precipitation, nor were significant amounts of

947 organic carbon incorporated into carbonate cements. Veining ceased during or soon after the onset of

948 exhumation. For veining to have stopped upon decompression is problematic, but could be explained

949 by the cessation of catagenesis or late-stage deformation being focused within fold limbs, leaving

950 hinges relatively relaxed by the time exhumation began.

951

952

\section{ACKNOWLEDGMENTS}

953

954 This study was funded by by Shell International Exploration and Production B.V. We gratefully acknowledge helpful contributions to chemical analyses by J. Barling, L. Tedeschi, M. Gilmour, and S. Nicoara; for core research support from Core Lab and G. Cubillos, and for management support from B. Westwood, S. James, D. Chang, L. Stockwell, and S. Naruk. This paper benefitted from discussion with M. Ruhl and J. English, and a critical review by T. Engelder.

959

\section{REFERENCES}

961

Aydin, A. and DeGraff, J.M., 1988, Evolution of polygonal fracture patterns in lava flows: Science, v. 239, no. 4839, p. 471-476.

Aydin, M.G. and Engelder, T., 2014, Revisiting the Hubbert-Rubey pore pressure model for overthrust faulting: Inferences from bedding-parallel detachment surfaces within Middle Devonian gas shale, the Appalachian Basin, USA: Journal of Structural Geology, v. 69 (B), p. 519-537. 
969

970

971

972

973

974

975

976

977

978

979

980

981

982

983

984

985

986

987

988

989

990

991

992

993

994

Banks, D.A., Davies, G.R., Yardley, B.W.D., McCaig, A.M., and Grant, N.T., 1991, The chemistry of brines from an Alpine thrust system in the Central Pyrenees: An application of fluid inclusion analysis to the study of fluid behaviour in orogenesis: Geochimica et Cosmochimica Acta, v. 55, p. 1021-1030.

Barker, S.L.L., Cox, S.F., Eggins, S.M., and Gagan, M.K., 2006, Microchemical evidence for episodic growth of antitaxial veins during fracture-controlled fluid flow: Earth and Planetary Science Letters, v. 250, p. $331-344$.

Becker, S.P., Eichhubl, P., Laubach, S.E., Reed, R.M., Lander, R.H., and Bodnar, R.J., 2010, A 48 m.y. history of fracture opening, temperature, and fluid pressure: Cretaceous Travis Peak Formation, East Texas basin: GSA Bulletin, v. 122, no. 7-8, p. 1081-1093.

Berner, U., Faber, E., and Stahl, W., 1992, Mathematical simulation of the carbon isotopic fractionation between huminitic coals and related methane: Chemical Geology, v. 94, p. 315-319.

Bisdom, K., Bertotti, G., and Nick, H.M., 2016, The impact of in-situ stress and outcrop-based fracture geometry on hydraulic aperture and upscaled permeability in fractured reservoirs:

Tectonophysics, doi:10.1016/j.tecto.2016.04.006.

Bjørlykke, K., 2014, Relationships between depositional environments, burial history and rock properties, Some principal aspects of diagenetic process in sedimentary basins: Sedimentary Geology, v. 301, p. 1-14.

Blount, C.W., 1977, Barite solubilities and thermodynamic quantities up to $300^{\circ} \mathrm{C}$ and 1400 bars: American Mineralogist, v. 62, p. 942-957. 
998

999

1000

1001

1002

1003

1004

1005

1006

1007

1008

1009

1010

1011

1012

1013

1014

1015

1016

1017

1018

1019

1020

1021
Blyth, A., Frape, S., Ruskeeniemi, T., and Blomqvist, R., 2004, Origins, closed system formation and preservation of calcites in glaciated crystalline bedrock: evidence from the Palmottu natural analogue site, Finland: Applied Geochemistry, v. 19, p. 675-686.

Bons, P.D., Elburg, M.A., and Gomez-Rivas, E., 2012, A review of the formation of tectonic veins and their microstructures: Journal of Structural Geology, v. 43, p. 33-62.

Bons, P.D. and Montenari, M., 2005, The formation of antitaxial calcite veins with well-developed fibres, Oppaminda Creek, South Australia: Journal of Structural Geology, v. 27, p. 231-248.

Bradley, D.C. and Kusky, T.M., 1986, Geologic evidence for rate of plate convergence during the Taconic arc-continent collision: The Journal of Geology, v. 94, no. 5, p. 667-681.

Breit, G.N., Goldhaber, M.B., Shawe, D.R., and Simmons, E.C., 1990, Authigenic barite as an indicator of fluid movement through sandstones within the Colorado Plateau: Journal of Sedimentary Petrology, v. 60, no. 6, p. 884-896.

Cai, J., Lu, X., and Li, B., 2015, Tectonic fracture and its significance in hydrocarbon migration and accumulation: a case study on middle and lower Ordovician in Taibei Uplift of Tarim Basin, NW China: Geological Journal, DOI: 10.1002/gj.2656.

Caputo, R. and Hancock, P.L., 1999, Crack-jump mechanism and its implications for stress cyclicity during extension fracturing: Geodynamics, v. 27, p. 45-60.

Cartwright, J., 2011, Diagenetically induced shear failure of fine-grained sediments and development of polygonal fault systems: Marine and Petroleum Geology, v. 28, p. 1593-1610. 
1022 Charlier, B.L.A., Ginibre, C., Morgan, D., Nowell, G.M., Pearson, D.G., Davidson, J.P., and Ottley,

1023 C.J., 2006, Methods for the microsampling and high-precision analysis of strontium and rubidium

1024 isotopes at single crystal scale for petrological and geochronological applications: Chemical Geology, 1025 v. 232, p. 114-133.

1026

1027

Chirita, P., 2004, Pyrite oxidation by hydrogen peroxide in phosphoric acid solutions: The European

Journal of Mineral Processing and Environmental Protection, v. 4, no. 3, 1303-0868, p. 203-209.

1029

1030

Coniglio, M., Frizzell, R., and Pratt, B.R., 2004, Reef-capping laminites in the Upper Silurian

1031

carbonate-to-evaporite transition, Michigan Basin, south-western Ontario: Sedimentology, v. 51, p.

1032 $653-668$.

1033

1034

Czerniakowski, L.A., Lohmann, K.C., and Wilson, J.L., 1984, Closed-system marine burial 1035 diagenesis: isotopic data from the Austin Chalk and its components: Sedimentology, v. 31, p. 863877.

1037

Demicco, R.V. and Smith, J., 2009, Sedimentologic observation and stratigraphic interpretation of the Lower Devonian (Lockhovian) Manlius Formation along the Mohawk River Valley in upstate New York: The Journal of Geology, v. 117, p. 543-551.

1041

Dewever, B., Swennen, R., and Breesch, L., 2013: Fluid flow compartmentalization in the Sicilian fold and thrust belt: Implications for the regional aqueous fluid flow and oil migration history:

1044 Tectonophysics, v. 591, p. 194-209.

1045

Diedrich, N.W. and Wilkinson, B.H., 1999, Depositional cyclicity in the Lower Devonian Helderberg Group of New York state: The Journal of Geology, v. 107, p. 643-658. 
Dietrich, D., McKenzie, J.A., and Song, H., 1983, Origin of calcite in syntectonic veins as determined 1050 from carbon-isotope ratios: Geology, v. 11, p. 547-551.

1051

1052

East, J.A., Swezey, C.S., Repetski, J.E., and Hayba, D.O., 2012, Thermal maturity map of Devonian 1053 shale in the Illinois, Michigan, and Appalachian basins of North America: United States Geological 1054 Survey Scientific Investigations Map 3214, 1 sheet, scale 1:24,000.

1055

1056

Egeberg, P.K. and Saigal, G.C., 1991, North Sea chalk diagenesis: cementation of chalks and healing of fractures: Chemical Geology, v. 92, p. 339-354.

1058

1059

1060

Emrich, K., Ehhalt, D.H., and Vogel, J.C., 1970, Carbon isotope fractionation during the precipitation of calcium carbonate: Earth and Planetary Science Latters, v. 8, p. 363-371.

1061

1062

Engelder, T., 1979, Mechanisms for strain within the Upper Devonian clastic sequence of the Appalachian plateau, western New York: American Journal of Science, v. 279, p. 527-542.

1064

1065

1066

1067

1068

1069

Engelder, T., Lash, G.G., and Uzcátegui, R.S., 2009, Joint sets that enchance production from Middle and Upper Devonian gas shales of the Appalachian Basin: AAPG Bulletin, v. 93, no. 7, p. 857-889.

Engelder, T. and Whitaker, A., 2006, Early jointing in coal and black shale: Evidence for an Appalachian-wide stress field as a predule to the Alleghanian orogeny: Geology, v. 34, no. 7, p. 581584.

English, J.M., 2012, Thermomechanical origin of regional fracture systems: AAPG Bulletin, v. 96, no. 9 , p. $1597-1625$. 
1078 Ettensohn, F.R., 1987, Rates of relative plate motion during the Acadian orogeny based on the spatial 1079 distribution of black shales: The Journal of Geology, v. 95, no. 4, p. 572-582.

1080

1081

Evans, M.A., 1994, Joints and décollement zones in Middle Devonian shales: Evidence for multiple 1082 deformation events in the central Appalachian Platea: GSA Bulletin, v. 106, no. 4, p. 447-460.

1083

1084

1085

Evans, M.A., 1995, Fluid inclusions in veins from Middle Devonian shales: A record of deformation conditions and fluid evolution in the Appalachian Plateau: GSA Bulletin, v. 107, no. 3, p. 327-339.

1086

1087

Evans, M.A., 2010, Temporal and spatial changes in deformation conditions during the formation of 1088 the Central Appalachian fold-and-thrust belt: Evidence from joints, vein mineral paragenesis, and 1089 1090 1091 fluig inclusions: in Tollo, R.P., Bartholomew, M.J., Hibbard, J.P., and Karabinos, P.M., eds., From Rodiania to Pangea: The Lithotectonic Record of the Appalachian Region, The Geological Society of America Memoir, v. 206, p. 477-552.

1092

1093

1094

Evans, M.A., Bebout, G.E., and Brown, C.H., 2012, Changing fluid conditions during folding: An example from the central Appalachians: Tectonophysics, v. 576-577, p. 99-115.

1095

1096

1097

1098

Evans, M.A., DeLisle, A., Leo, J., and Lafonte, C.L., 2014; Deformation conditions for fracturing in the Middle Devonian sequence of the central Appalachians during the Late Paleozoic Alleghanian orogeny: AAPG Bulletin, v. 98, no. 11, p.2263-2299.

1099

Faill, R.T., 1973, Kink-band folding, Valley and Ridge province, Pennsylvania: GSA Bulletin, v. 84, 1101 no. 4, p. 1289-1314. 
Fergusson, W.B. and Prather, B.A., 1968, Salt deposits in the Salina Group in Pennsylvania:

1104 Commonwealth of Pennsylvania Department of Internal Affairs, Bureau of Topographic and Geologic

1105 Survey, Mineral Resources Report, v. M 58, 41 p.

1106

1107

Gale, J.F.W., Laubach, S.E., Olson, J.E., Eichhubl, P. and Fall, A., 2014, Natural fractures in shale: A review and new observations: AAPG Bulletin, v. 98, no. 11, p. 2165-2216.

1109

Galimov, E.M., 2006, Isotope organic geochemistry: Organic Geochemistry, v. 37, p. 1200-1262.

Gao, G., Elmore, R.D., and Land, L.S., 1992, Geochemical constraints on the origin of calcite veins and associated limestone alteration, Ordovician Viola Group, Arbuckle Mountains, Oklahoma,

U.S.A.: Chemical Geology, v. 98, p. 257-269.

1115

Gillespie, P., van Hagen, J., Wessels, S., and Lynch, D., 2015, Hierarchical kink band development in the Appalachian Plateau decollement sheet: AAPG Bulletin, v. 99, no. 1, p. 51-76. $33-48$.

1122

Goldstein, R.H. and Reynolds, T.J., 1994, Systematics of fluid inclusions in diagenetic minerals:

SEPM Short Course Notes, v. 31, 199 p.

Gould, K.W. and Smith, J.W., 1979, The genesis and isotopic composition of carbonates associated with some Permian Australian coals: Chemical Geology, v. 24, p. 137-150.

Griffith, E. M. and Paytan, A., 2012, Barite in the ocean - occurrence, geochemistry and palaeoceanographic applications: Sedimentology, doi: 10.1111/j.1365-3091.2012.01327.x. 
1132 Haeri-Ardakani, O., Al-Aasm, I., and Coniglio, M., 2013, Fracture mineralization and fluid-flow

1133 evolution: an example from Ordovician Devonian carbonates, southwestern Ontario, Canada:

1134 Geofluids, v. 13, p. 1-20.

1135

1136

Hatcher, R.D., Jr., 1981, Thrusts and nappes in the North American Appalachian orogen: in McClay,

K.R. and Price, N.J., eds., Thrust and Nappe Tectonics, Geological Scoiety (London) Special

Publication, v. 9, p. 491-499.

Henry, C., Burkhard, M., and Goffé, B., 1996, Evolution of synmetamorphic veins and their wallrocks

through a Western Alps transect: no evidence for large-scale fluid-flow. Stable isotope, major- and trace-element systematics: Chemical Geology, v. 127, p. 81-109.

Héroux, Y., Chagnon, A., and Savard, M., 1996, Organic matter and clay anomalies associated with base-metal sulfide deposits: Ore Geology Reviews, v. 11, p. 157-173.

Hillier, R.D. and Cosgrove, J.W., 2002, Core and seismic observations of overpressure-related deformation within Eocene sediments of the Outer Moray Firth, UKCS: Petroleum Geoscience, v. 8, p. 141-149.

Hooker, J.N., Laubach, S.E., and Marrett, R., 2014, A universal power-law scaling exponent for

1152 fracture apertures in sandstones: GSA Bulletin, v. 126, no. 9/10, p. 1340-1362.

Hooker, J.N. and Katz, R.F., 2015, Vein spacing in extending, layered rock: the effect of synkinematic cementation: American Journal of Science, v. 315, p. 557-588. 
Hooker, J.N., Larson, T.E., Eakin, A., Laubach, S.E., Eichhubl, P., Fall, A., and Marrett, R., 2015,

1158 Fracturing and fluid flow in a sub-decollement sandstone; or, a leak in the basement: Journal of the

1159 Geological Society [London], v. 172, p. 428-442.

1160

1161

Hudson, J.D., 1975, Carbon isotopes in limestone cement: Geology, v. 3, p. 19-22.

1162

1163

Indiana University Paleontology Seminar, 1976, Silurian reef complex, Rockford, Ohio: constitution, growth, and significance: AAPG Bulletin, v. 60, no. 3, p. 428-451.

1165

Johri, M. and Zoback, M.D., 2013, The evolution of stimulated reservoir volume during hydraulic

stimulation of shale gas formations: Unconventional Resources Technology Conference, Denver,

Colorado, USA, 12-14 August 2013, paper 1575434, 11 p.

1169

Jung, B., Garven, G., and Boles, J.R., 2015, The geodynamics of faults and petroleum migration in the

Los Angeles basin, California: American Journal of Science, v. 315, p. 412-459.

Kim, S.-T. and O’Neil, J.R., 1997, Equilibrium and nonequilibrium oxygen isotope effects in

Kindle, E.M., 1917, Factors affecting the development of mud-cracks: Journal of Geology, v. 25, no. 2, p. 135-144.

Lacazette, A. and Engelder, T., 1992, Fluid-driven cyclic propagation of a joint in the Ithaca Siltstone, 
Lander, R.H., Larese, R.E., and Bonnell, L.M., 2008, Toward more accurate quartz cement models:

1184 The importance of euhedral versus noneuhedral growth rates: AAPG Bulletin, v. 92, no. 11, p. 1537-

11851563.

1186

1187

Lander, R.H. and Laubach, S.E., 2015, Insights into rates of fracture growth and sealing from a model for quartz cementation in fractured sandstones: GSA Bulletin, v. 127, no. 3/4, p. 516-538.

1189

Lash, G.G., 2006, Top seal development in the shale-dominated Upper Devonian Catskill Delta

Complex, western New York State: Marine and Petroleum Geology, v. 23, p. 317-335.

1192

1193

Lash, G., Loewy, S., and Engelder, T., 2004: Preferential jointing of Upper Devonian black shale,

Appalachian Plateau, USA: evidence supporting hydrocarbon generation as a joint-driving

mechanism: in Cosgrove, J.W. and Engelder, T., eds., The Initiation, Propagation, and Arrest of Joints and Other Fractures: Geological Society [London] Special Publications, v. 231, p. 129-151.

Lash, G.G. and Blood, D.R., 2014, Organic matter accumulation, redox, and diagenetic history of the

Marcellus Formation, southwestern Pennsylvania, Appalachian basin: Marine and Petroleum

Geology, v. 57, p. 244-263.

1201

Lash, G.G. and Engelder, T., 2005, An analysis of horizontal microcracking during catagenesis:

Example from the Catskill delta complex: AAPG Bulletin, v. 89, no. 11, p. 1433-1449.

Lash, G.G. and Engelder, T., 2011, Thickness trends and sequence stratigraphy of the Middle 
Leythaeuser, D., Borromeo, O., Mosca, F., di Primio, R., Radke, M., and Schaefer, R.G., 1995,

Pressure solution in carbonate source rocks and its control on petroleum generation and migration.

Marine and Petroleum Geology, v. 12, no. 7, p. 717-733.

Lumsden, D.N., 1988, Characteristics of deep-sea dolomite: Journal of Sedimentary Petrology, v. 58, no. 6 , p. $1023-1031$.

Machel, H.G., Krouse, H.R., and Sassen, R., 1995, Products and distinguishing criteria of bacterial and thermochemical sulfate reduction: Applied Geochemistry, v. 10, p. 373-389.

Maliva, R.G., Dickson, J.A.D., and Råheim, A., 1991, Modelling of chalk diagenesis (Eldfisk Field, Norwegian North Sea) using whole rock and laser ablation stable isotopic data: Geological Magazine, v. 128 , no. 1 , p. $43-49$.

Marshak, S., 1988, Kinematics of orocline and arc formation in thin-skinned orogens: Tectonics, v. 7, no. 1, p. $73-86$.

McLaughlin, J.F., Frost, C.D., and Sharma, S., 2011, Geochemical analysis of Atlantic Rim water, Carbon County, Wyoming: New applications for characterizing coalbed natural gas reservoirs: AAPG Bulletin, v. 95, no. 2, p. 191-217.

Mount, V.S., 2014, Structural style of the Appalachian Plateau fold belt, north-central Pennsylvania: Journal of Structural Geology, v. 69, p. 284-303.

Oliver, W.A., Jr., 1954, Stratigraphy of the Onondaga Limestone (Devonian) in central New York: GSA Bulletin, v. 65, p. 621-652. 
Oliver, J., 1986, Fluids expelled tectonically from orogenic belts: Their role in hydrocarbon migration and other geoloic phenomena: Geology, v. 14, p. 99-102.

Ortega, O.J., Marrett, R., and Laubach, S.E., 2006, A scale-independent approach to fracture intensity and average spacing measurement: AAPG Bulletin, v. 90, no. 2, p. 193-208.

Osborn, S.G. and McIntosh, J.C., 2010, Chemical and isotopic tracers of the contribution of microbial gas in Devonian organic-rich shales and reservoir sandstones, northern Appalachian Basin: Applied Geochemistry, v. 25, p. 456-471.

Osborn, S.G., McIntosh, J.C., Hanor, J.S., and Biddulph, D., 2012, Iodine-129, 87Sr/86Sr, and trace elemental geochemistry of northern Appalachian basin brines: evidence for basinal-scale fluid migration and clay mineral diagenesis: American Journal of Science, v. 312, p. 263-287.

Pashin, J.C., McIntye-Redden, M.R., Mann, S.D., Kopaska-Merkel, D.C., Varonka, M., and Orem, W., 2014, Relationships between water and gas chemistry in mature coalbed methane reservoirs of the Black Warrior Basin: International Journal of Coal Geology, v. 126, p. 92-105.

Pitman, J.K., Pashin, J.C., Hatch, J.R., and Goldhaber, M.B., 2003, Origin of minerals in joint cleat systems of the Pottsville Formation, Black Warrior basin, Alabama: Implications for coalbed methane generation and production: AAPG Bulletin, v. 87, no. 5, p. 713-731.

Pommer, L., Gale, J.F.W., Eichhubl, P., Fall, A., and Laubach, S.E., 2013, Using structural diagenesis to infer the timing of natural fractures in the Marcellus Shale: Unconventional Resources Technology Conference, Denver, Colorado, USA, 12-14 August 2013, paper 1580135, 6 p. 
Rabinowicz, M., Dandurand, J.-L., Jakubowski, M., Schott, J., and Cassan, J.-P., 1985, Convection in

1263 a North Sea oil reservoir: inferences on diagenesis and hydrocarbon migration: Earth and Planetary

1264 Science Letters, v. 74, p. 387-404.

1265

1266

Rodgers, J., 1970, The Tectonics of the Appalachians, A Volume in the Regional Geology Series (ed.

L.U. de Sitter). New York: John Wiley \& Sons, 271 p.

1268

1269

Ryb, U., Erel, Y., Matthews, A., Avni, Y., Gordon, G.W., and Anbar, A., 2009, Large molybdenum isotope variations trace subsurface fluid migration along the Dead Sea Transform: Geology, v. 37, no. 5, p. 463-466.

1272

Sak, P.B., McQuarrie, N., Oliver, B.P., Lavdovsky, and Jackson, M.S., 2012, Unraveling the central

Appalachian fold-thrust belt, Pennsylvania: The power of sequentially restored balanced cross sections for a blind fold-thrust belt: Geosphere, v. 8, no. 3, p. 685-702.

1276

Scanlin, M.A. and Engelder, T., 2003, The basement versus the no-basement hypotheses for folding within the Appalachian plateau detachment sheet: American Journal of Science, v. 303, p. 519-563.

Schobert, H. H., 1990, The Chemistry of Hydrocarbon Fuels. London: Butterworths, 348 p.

1281

Shock, E.L., Helgeson, H.C., and Sverjensky, D.A., 1989, Calculation of the thermodynamic and transport properties of aqueous species at high pressures and temperatures: Standard partial molal properties of inorganic neutral species: Geochimica et Cosmochimica Acta, v. 53, p. 2157-2183.

Siever, R., 1962 , Silica solubility, $0^{\circ}-200^{\circ}$ C., and the diagenesis of siliceous sediments: The Journal of Geology, v. 70, no. 2, p. 127-150. 
Srivastava, D.C. and Engelder, T., 1990, Crack-propagation sequence and pore-fluid conditions during fault-bend folding in the Appalachian Valley and Ridge, central Pennsylvania: GSA Bulletin, v. 102 , p. 116-128.

Stephenson, B., Cartwright, J., Hooker, J.N., and Hnat, J., 2015, What actually controls SRV? Three concepts to debate a stimulation or stimulate a debate!: SPE Unconventional Resources Conference, Calgary, Alberta, Canada, 20-22 October 2015, paper 175909, 10 p.

Stephenson, B. and Coflin, K., 2015, Guidelines for the handling of natural fractures and faults in hydraulically stimulated resource plays: SPE Unconventional Resources Conference, Calgary, Alberta, Canada, 20-22 October 2015, paper 175910, 18 p.

Torres, M.E., Brumsack, H.J., Bohrmann, G., and Emeis, K.C., 1996, Barite fronts in continental margin sediments: A new look at barium remobilization in the zone of sulfate reduction and formation of heavy barites in diagenetic fronts: Chemical Geology, v. 127, p. 125-139.

Veizer, J., Ala, D., Azmy, K., Bruckschen, P., Buhl, D., Bruhn, F., Carden, G.A.F., Diener, A., Ebneth, S., Godderis, Y., Jasper, T., Korte, C., Pawallek, F., Podlaha, O., and Strauss, H., 1999, ${ }^{87} \mathrm{Sr} /{ }^{86} \mathrm{Sr}, \delta^{13} \mathrm{C}$ and $\delta^{18} \mathrm{O}$ evolution of Phanerozoic seawater: Chemical Geology, v. 161, p. 59-88.

Verlaguet, A., Goffé, B., Brunet, F., Poinssot, C., Vidal, O., Findling, N., and Menut, D., 2011, Metamorhpic veining and mass transfer in a chemically closed system: a case study in Alpine metabauxites (western Vanoise): Journal of Metamorphic Geology, v. 29, p. 275-300.

Vilasi, N., Malandain, J., Barrier, L., Callot, J.-P., Amrouch, K., Guilhaumou, N., Lacombe, O., Muska, K., Roure, F., and Swennen, R., 2009, From outcrop and petrographic studies to basin-scale fluid-flow modelling: The use of the Albanian natural laboratory for carbonate reservoir characterisation: Tectonophysics, v. 474, p. 367-392. 
1318 Wang, G. and Carr, T.R., 2013, Organic-rich Marcellus Shale lithofacies modeling and distribution 1319 pattern analysis in the Appalachian Basin: AAPG Bulletin, v. 97, no. 12, p. 2173-2205.

Wangen, M. and Munz, I.A., 2004, Formation of quartz veins by local dissolution and transport of silica: Chemical Geology, v. 209, p. 179-192.

Wazir, I., Pagel, M., Tournier, F., Portier, E., and Renac, C., 2014, Role of compressive tectonics on gas charging into the Ordovician sandstone reservoirs in the Sbaa Basin, Algeria: constrained by fluid inclusions and mineralogical data: Geofluids, v. 14, p. 106-126.

Welton, J., 2003, SEM Petrology Atlas: AAPG Methods in Exploration Series, v. 4, Tulsa, 240 p.

Wilkins, S., Mount, V., Mahon, K., Perry, A., and Koenig, J., 2014, Characterization and devlopment of subsurface fractures observed in the Marcellus Formation, Appalachian Plateau, north-central Pennsylvania: AAPG Bulletin, v. 98, no. 11, p. 2301-2345.

Wiltschko, D.V. and Morse, J.W., 2001, Crystallization pressure versus "crack seal" as the mechanism for banded veins: Geology, v. 29, p. 79-82.

Worden, R.H., Benshatwan, M.S., Potts, G.J., and Elgarmadi, S.M., 2015, Basin-scale fluid movement patterns revealed by veins: Wessex Basin, UK: Geofluids, doi: 10.1111/gfl.12141.

Yeh, H.-W., and Savin, S.M., 1977, Mechanism of burial metamorphism of argillaceous sediments: 3. 
Younes, A.I. and Engelder, T., 1999, Fringe cracks: Key structures for the interpretation of the

1344 progressive Alleghanian deformation of the Appalachian plateau: GSA Bulletin, v. 111, no. 2, p. 219-

1345239

FIGURE CAPTIONS

Figure 1. Map of study area. Thin black lines are anticline traces, after Wilkins et al. (2014). Thin

gray lines are isopach contours of the Silurian Salina Group, after Fergusson and Prather, 1968;

contour interval $=200 \mathrm{ft}$. Core locations $(\mathrm{A}, \mathrm{F}, \mathrm{S})$, pproximate locations $(\mathrm{P})$, and outlines of Tioga and

Lawrence counties shown.

1353

Figure 2. Stratigraphic section of the Appalachian basin, compiled from Osborn and McIntosh (2010),

Osborn et al. (2012), Wang and Carr (2013), Aydin and Engelder (2014), and Wilkins et al. (2014).

Figure 3. Regional stratigraphic and structural trends. Salina Group thickness contours (Fergusson and Prather, 1968) added for comparison. Contour interval $=200$ feet; see Figure 1 for scale and contour values. Observations from core photo database; maximum and minimum values shown; circles scaled by area. (A) Thickness in meters from top of Upper Marcellus to bottom of Lower Marcellus. (B) total vein frequency, number per meter of core. (C) Frequency of layer-parallel pyrite veins, number per meter of core. Note generally greater frequency in Lower Marcellus compared to Upper Marcellus. (D) Frequency of faults and mineral- or slickenside-lined rubble zones, number per meter of core. (E) Example core photo; four columns on the right form a rubble zone with abundant mineral linings.

Figure 4. Fractures observed on FMI logs, Well and Core F. Compare (A) image log and (B) core. In image log, resistive (light) sinusoids indicate sealed fractures at high angle to bedding (loweramplitude sinusoids). (C) Interpreted fractures $(\mathrm{N}=1153)$ from the horizontal part of wellbore $\mathrm{A}$, landed within Lower Marcellus. Measured depths in feet. Rose diagram shows fracture strikes. (D) Stereonet of bedding data shows most beds horizontal. A fold was intersected between 9000 and 
10000 feet. (E) Interpreted fractures in cross-section view. Fracture dip changes from one fold limb to

1372 the other.

Figure 5. (A-C) Fracture apertures, orientation, and dominant filling minerals with depth, Cores F, A,

S. (D) Fracture intensity (summed aperture normalized to host-unit thickness), summed from Cores F,

$\mathrm{A}$, and $\mathrm{S}$.

Figure 6. Wispy-tipped fractures. S: stylolite. (A) Core F, $5670.5 \mathrm{ft}$ (Onondaga Limestone). Note discrete layer-parallel surface where tips begin, interpreted to be a stylolite. (B, C) In carbonate-rich mudrock layers, Core P (8533 and 8552 ft., respectively - Utica Shale). Note bitumen in (B) and (C), which contains tiny fractures filled with calcite. Vein in (C) has right-stepping en-échelon segments.

Figure 7. Vein height (or length, for layer-parallel fractures) versus aperture. Blunt-tip refers to fractures whose tips terminate at bedding planes or other layer-parallel features, enabling fracture widening without lengthening. Power-law equation fit to all fracture types combined. Poor correlation reflects the variety of aspect ratios observed.

Figure 8. Shear fractures and related veins in core. S: stylolite. (A) Calcite-lined fault, Core F, 5549.5 $\mathrm{ft}$ (Cherry Valley Limestone). Note pore space preserved. (B) Calcite- and pyrite-lined fault at low angle to bedding, Core F, $5658.1 \mathrm{ft}$ (Lower Marcellus). (C) Detail showing striated fault plane in (B). (D) Calcite- and bitumen-filled vein, Core A, $5665.5 \mathrm{ft}$ (Lower Marcellus). Note striae along bedding

Figure 9. Pyrite concretion morphologies and hypothetical fracture-pyrite relationships. All black scale bars $=1 \mathrm{~cm}$. Gold color in illustrations, pyrite. Brown, host shale. White, calcite. Black lines, bedding. 
Figure 10. Host rocks. Ba: barite; Bit: bitumen; Cal: calcite; Dol: dolomite; ill: illite; Pyr: pyrite; Q: quartz. (A) EDS map of clay and pyrite-rich mudstone, Lower Marcellus, Core F, depth $5642.6 \mathrm{ft}$. Clay is primarily illite; note abundant silicate and carbonate detrital grains. Most pyrite is framboidal but blocky pyrite is also present. Note also blocky quartz cement within layer-parallel, elliptical pore. (B) EDS map of quartz- and dolomite-cemented marl, Upper Marcellus, Core S, depth $4840.0 \mathrm{ft}$. Abundant diagenetic dolomite and quartz is present; original sedimentary texture is faint. (C) Planepolarized light image of fossiliferous rock hosting calcite-bitumen vein, Utica Shale, Core P, depth $8514.8 \mathrm{ft}$. (D) BSE image of clay, detrital silicate, and pyrite-rich mudrock, Upper Marcellus, Core A, depth $5548.9 \mathrm{ft}$. Note barite coating illite flakes. (E) BSE image of fossiliferous, pyrite-rich mudrock, Upper Marcellus, Core F, depth $5506.3 \mathrm{ft}$. Note barite filling fossil.

Figure 11. Major components of host rocks and veins, from point counts of mudrock samples. Diagonal line in each plot marks 1:1 correspondence.

Figure 12. Vein fill styles. (A) Blocky euhedral calcite cement, Core A, $5661.0 \mathrm{ft}$ (Lower Marcellus). (B) Cross-polarized light photomicrograph, blocky calcite with bitumen (black) at vein cemter, Core P, $8533.1 \mathrm{ft}$ (Utica Shale). (C) Cross-polarized light photomicrograph, vein with fibrous (F) and stretched (S) crystal morphologies, Core F, $5506.5 \mathrm{ft}$ (Upper Marcellus). Note fracture-parallel inclusions within stretched crystals, indicating repeated cracking and sealing of vein fill.

Figure 13. Vein with crenulated walls and micro-blocky fill texture, both possibly results of late recrystallization. Core F, depth 5642.6 ft (Lower Marcellus). (A) Core-scale. (B) Plane-polarised image. Inset: SE image. Cal: calcite; Q: quartz. Note sphalerite cement is present near microconcretion of the same mineral in the host rock.

Figure 14. Vein filling minerals. Bar: barite; Cal: calcite; Pyr: pyrite; Q: quartz. (A) Vein with pyrite at margins and micro-blocky fill in the center, comprising pyrite, calcite, and barite crystals (Inset 1). Blocky texture suggests syntaxial fill (from the margins toward the center). Lower along the fracture 
(Inset 2) the aperture is narrower. Late dolomite is present near center of fracture. Trace quartz along

1427 the margins might reflect late-stage recrystallization; note the fracture walls are particularly crenulated where quartz is present. Core A, $5548.9 \mathrm{ft}$ (Upper Marcellus). (B) Layer-parallel vein within pyrite-barite concretion, Core S, depth $4829.6 \mathrm{ft}$ (Upper Marcellus). Rare example of polymineralic layer-parallel vein. Note the same apparent mineral precipitation sequence in (A) and (B) (Inset 3). Also note compacted vein and rotation of host sediment at margin of concretion (Inset $4)$.

Figure 15. Bitumen- and carbonate-filled veins. (A-C) Lower Marcellus, Core F, $5553.7 \mathrm{ft}$; (D) Utica Fm., Core P, depth 8551.6 ft. Ba--barite; Bit--bitumen; Cal--calcite; Dol--dolomite. (A) Crosspolarized light photomosaic. Fracture is lines with dolomite bearing small bitumen inclusions. Later calcite overlies dolomite and fills fractures within large bitumen deposit at fracture middle. (B) Crosspolarized light photomicrograph. The same mineral sequence is present, with early dolomite bridging across fracture. (C) EDS map showing early dolomite partially recrystallized to calcite. (D) Calcitebitumen vein with trace barite in the vicinity of bitumen.

Figure 16. Veins in Oriskany Sandstone with quartz cement and pore space. CS: crack-seal texture; P: pore space; Q: quartz cement. (A) Core photo, Core F, depth $5682.3 \mathrm{ft}$. Arrow indicates fracture imaged in (B-E). (B) SE image highlighting porosity. (C) CL image of same area as in (B), showing crack-seal texture within quartz bridges. (D) SE image. (E) CL image, same area as (D).

Figure 17. Isotopic compositions of calcite veins and their mudrock host-rocks. All carbon and oxygen values given in \% VPDB. Diagonal line in $(\mathrm{A}-\mathrm{C})$ represents 1:1 correspondence between vein and host-rock isotopic composition. (A) Oxygen and carbon, subdivided by vein orientation. (B) Same data as in (A) but subdivided by host formation. (C) Strontium. Shaded area represents range of depositional seawater, from Veizer et al. (1999). Vein strontium is consistently heavier than host-rock carbonate but lighter than bulk host-rock and non-carbonate host-rock (Table 2). (D) Carbon compositions of bitumen within five bitumen-bearing veins, Core P. 
Figure 18. Layer-parallel fibrous vein, Core S, depth $4859.6 \mathrm{ft}$ (Lower Marcellus). (A) Cross-polaized light image, showing medial zone and fibrous zones A and B, above and below. True up-direction is unknown, because core pieces may have been inverted during handling. (B) Carbon and oxygen compositions, in \%o VPDB. Note zone A has carbon close to that of the host rock while zone B has enriched carbon. Both sections have similar oxygen composition, which is depleted relative to the host rock. (C) Backscatter image of barite within fibrous zone A, implying a distinct and probably later timing relative to fibrous zone $\mathrm{B}$; see text.

Figure 19. Paragenetic sequence and schematic depth-time curve for Marcellus Formation shale layers. Note fracturing ceases during or soon after maximum burial. Maximum burial depth approximated from Evans et al. (2014) and Wilkins et al. (2014).

Figure 20. Schematic of oxygen isotopic evolution model. Size of arrows represents relative contribution to dissolution-reprecipitation, which is proportional to the current volume of the component being dissolved or reprecipitated. Shade of water and carbonate portions represents oxygen composition (dark is heavy). Isotopic exchange with silicates and organic matter is neglected; see text.

Figure 21. Oxygen model output. Shaded area represents the observed variation (one standard deviation). $\mathrm{M}$ is the ratio of carbonate to water in the host material. For fracture opening during prograde burial, note $\Delta 18 \mathrm{O}(\mathrm{V}-\mathrm{HR})$ is near the observed $\sim-1 \%$ value over a wide range of carbonate volumes reprecipitated. For fracture opening during exhumation, note $\Delta 18 \mathrm{O}(\mathrm{V}-\mathrm{HR})$ quickly homogenizes under cooling conditions. on crosscutting relationships. 
Table 2. Isotopic data.

AUTHOR VITAE

1485

J.N. Hooker University of Oxford, Department of Earth Sciences, South Parks Road, Oxford, OX1

3AN, United Kingdom; john.hooker@earth.ox.ac.uk.

John N. Hooker is a postdoctoral research associate at the University of Oxford. He earned his BA,

MS, and PhD from The University of Texas at Austin. His research interests include the evolution of natural fracture patterns and the dynamics among crustal deformation, diagenetic reactions, and fluid flow.

1493

J. Cartwright $\sim$ University of Oxford, Department of Earth Sciences, South Parks Road, Oxford, OX1 3AN, United Kingdom; joe.cartwright@earth.ox.ac.uk.

Joe Cartwright is Shell Professor of Earth Sciences at the University of Oxford. He worked for Shell International as an exploration geophysicist, at Imperial College as a Senior Lecturer, and at Cardiff University as a Research Professor. His research is based on seismic interpretation, and has ranged from normal-fault propagation, polygonal fault systems, sandstone and igneous intrusions, to submarine slides and other forms of sediment deformation. His current interests embrace the seismic characterisation of mudrocks as seals, hydrocarbon migration, and fracture development in shales.

B. Stephenson Shell Canada Energy, 400 - 4th Ave S.W., Calgary, Alberta, T2P 2H5, Canada; Ben.Stephenson@shell.com.

Ben Stephenson has a degree in Earth Sciences from Cambridge and a D. Phil. from Oxford on 
worked for 18 years. Ben has enjoyed many roles in operations, research, technology deployment, technical assurance, reservoir characterization and field development and has worked on conventional and unconventional assets globally.

C.R.P. Silver Shell E\&P Co., Houston, Texas, 77079, USA; Calvin.Silver@shell.com.

Calvin R.P. Silver is a petroleum geologist at Shell E\&P in Houston. He has his B.S. and M.S. in geology from the University of Houston, his focus on Himalayan neotectonics. He has worked the conventional onshore Gulf Coast, the unconventional Mississippi Lime and Marcellus Shale, and the offshore deep water Gulf.

A.J. Dickson University of Oxford, Department of Earth Sciences, South Parks Road, Oxford, OX1 3AN, United Kingdom; alex.dickson@earth.ox.ac.uk.

Alex Dickson is a postdoctoral geochemist at the University of Oxford. His current research projects include developing novel isotopic methods for characterizing source-rocks, studying the relationships between trace metals and organic matter using natural systems and laboratory experiments, and using inorganic and organic geochemical methods to reconstruct past marine depositional conditions during the Phanerozoic.

Y.-T. Hsieh University of Oxford, Department of Earth Sciences, South Parks Road, Oxford, OX1 3AN, United Kingdom; yu-te.hsieh@earth.ox.ac.uk.

Yu-Te (Alan) Hsieh is a multi-collector mass spectrometer lab manager at the Department of Earth 
1538 MC-ICP-MS and TIMS. He is also an isotope geochemist with a particular interest in U-series and 1539 non-traditional stable isotopes in marine chemistry and paleoceanography. 
A Marcellus thickness
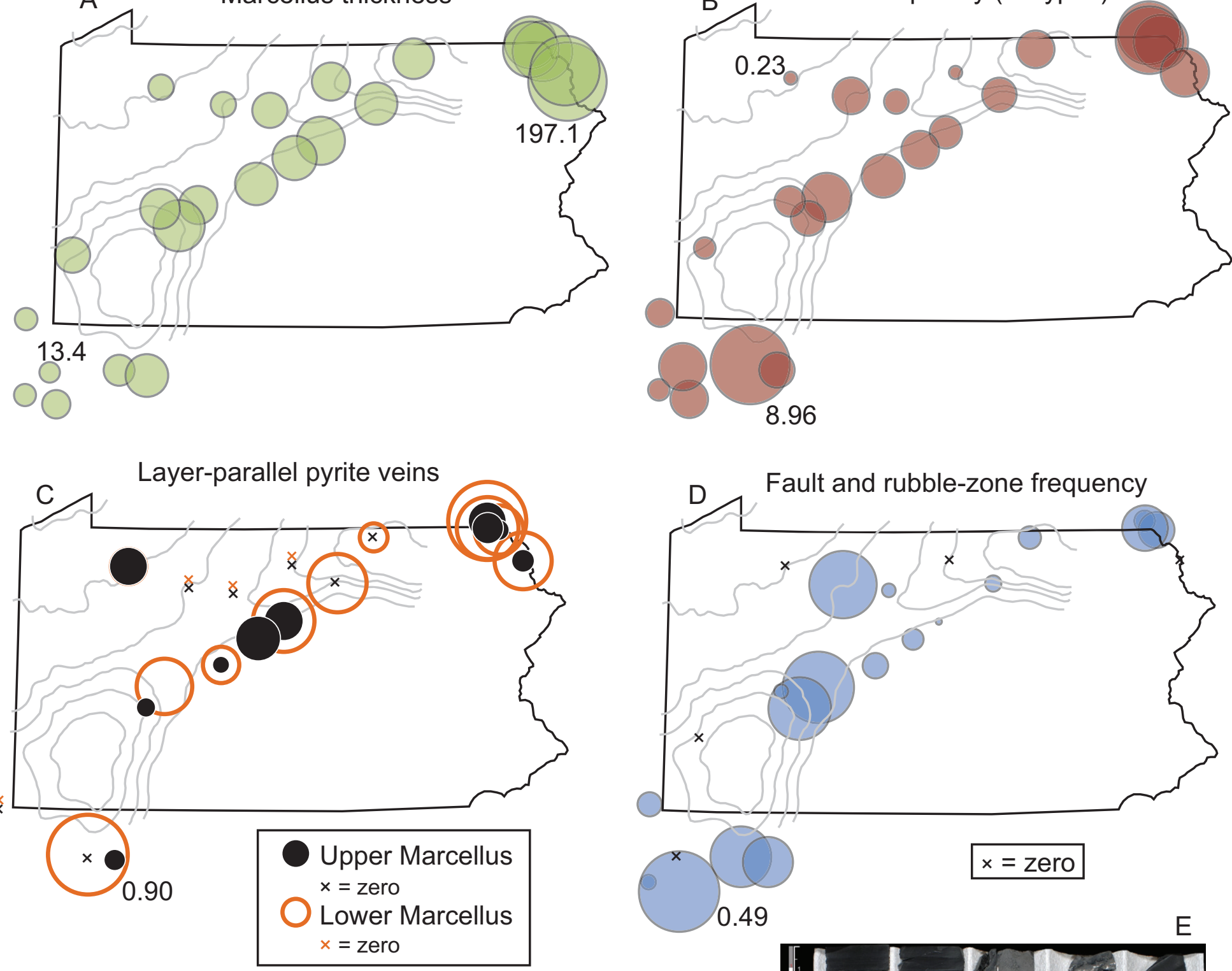

Figure 3. Regional stratigraphic and structural trends. Salina Group thickness contours (Fergusson and Prather, 1968) added for comparison. Contour interval = 200 feet; see Figure 1 for scale and contour values. Observations from core photo database; maximum and minimum values shown; circles scaled by area. (A) Thickness in meters from top of Upper Marcellus to bottom of Lower Marcellus. (B) total vein frequency, number per meter of core. (C) Frequency of layer-parallel pyrite veins, number per meter of core. Note generally greater frequency in Lower Marcellus compared to Upper Marcellus. (D) Frequency of faults and mineral- or slickenside-lined rubble zones, number per meter of core. (E) Example core photo; four columns on the right form a rubble zone with abundant mineral

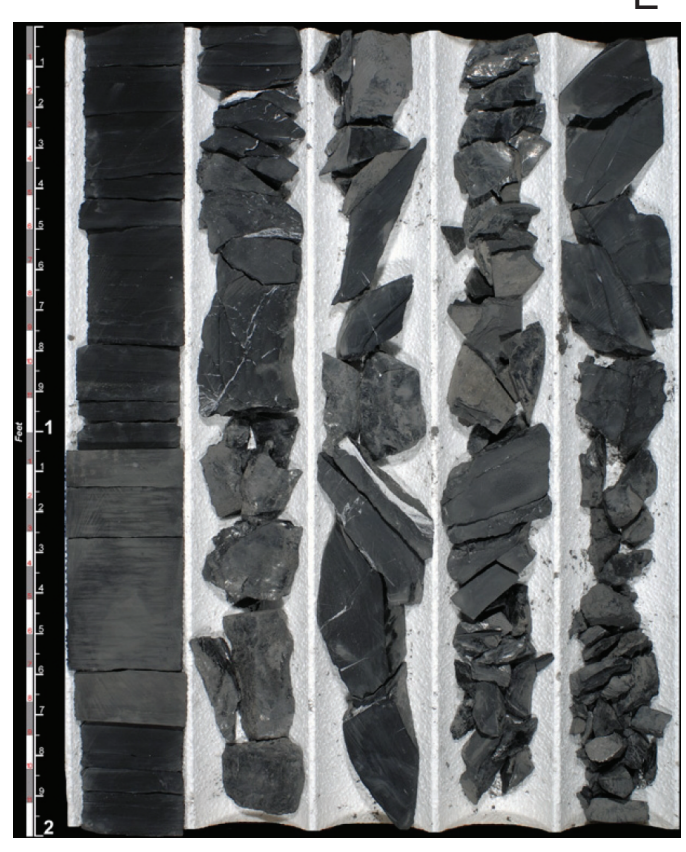
linings. 


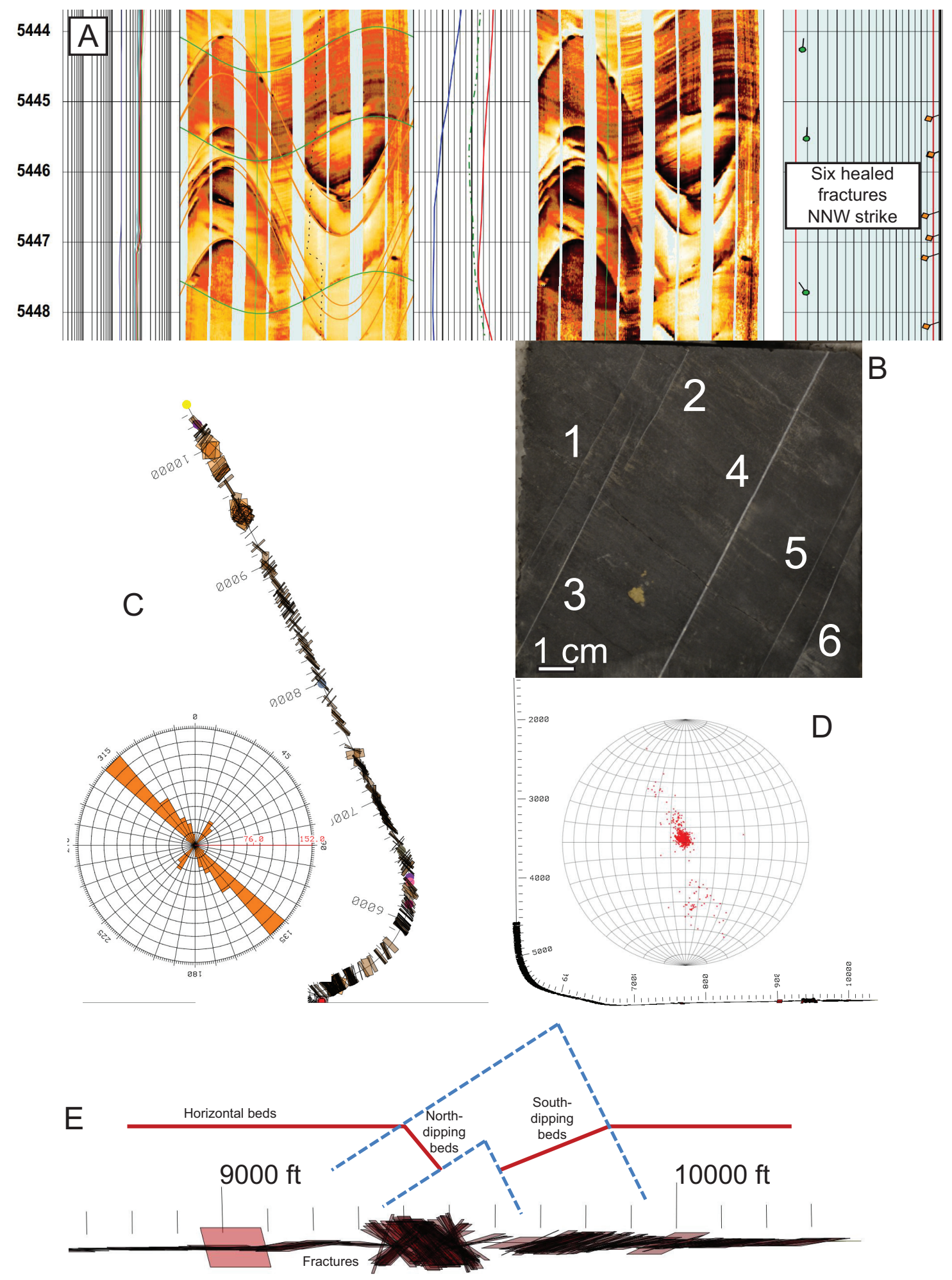

Figure 4. Fractures observed on FMl logs, Well and Core F. Compare (A) image log and (B) core. In image log, resistive (light) sinusoids indicate sealed fractures at high angle to bedding (lower-amplitude sinusoids). (C) Interpreted fractures $(\mathrm{N}=1153$ ) from the horizontal part of wellbore $\mathrm{A}$, landed within Lower Marcellus. Measured depths in feet. Rose diagram shows fracture strikes. (D) Stereonet of bedding data shows most beds horizontal. A fold was intersected between 9000 and 10000 feet. (E) Interpreted fractures in cross-section view. Fracture dip changes from one fold limb to the other. 

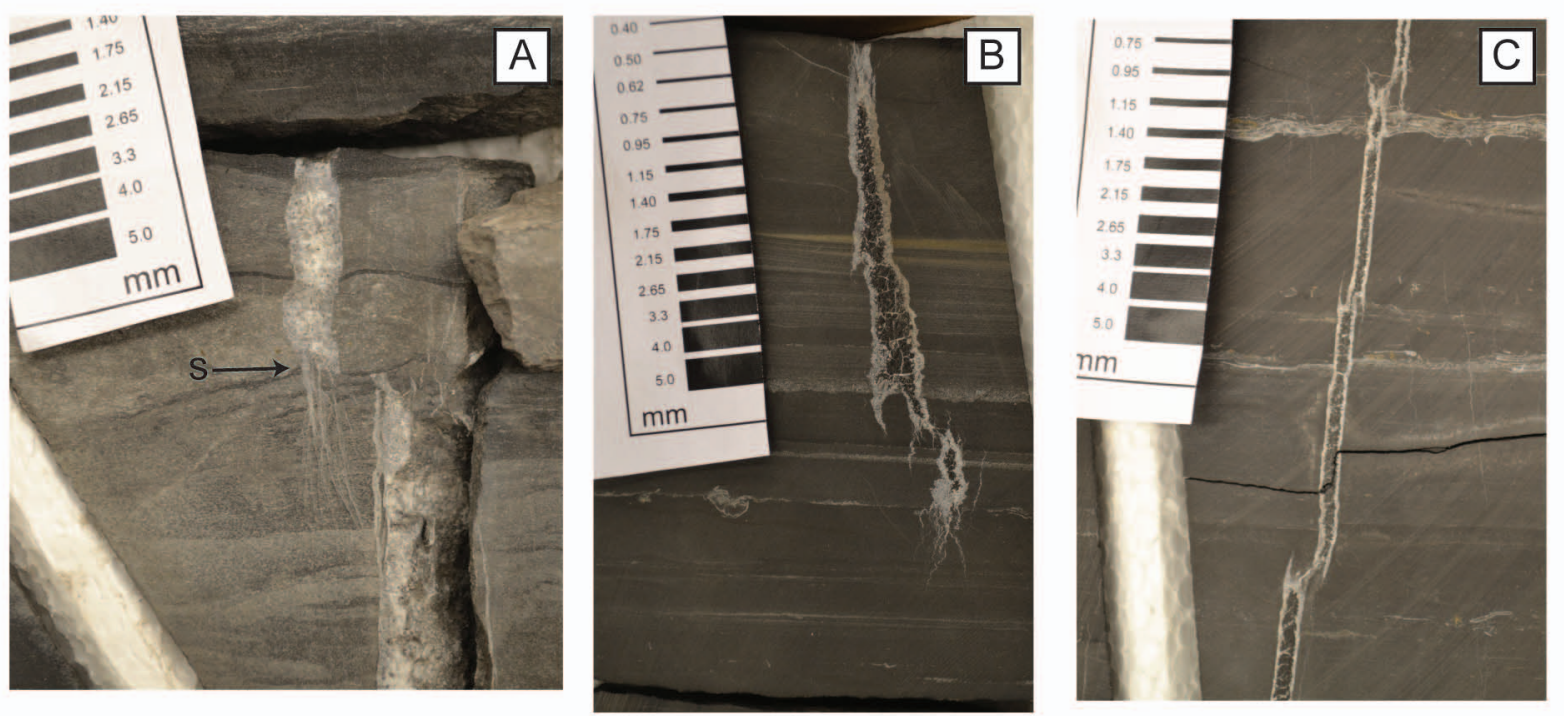


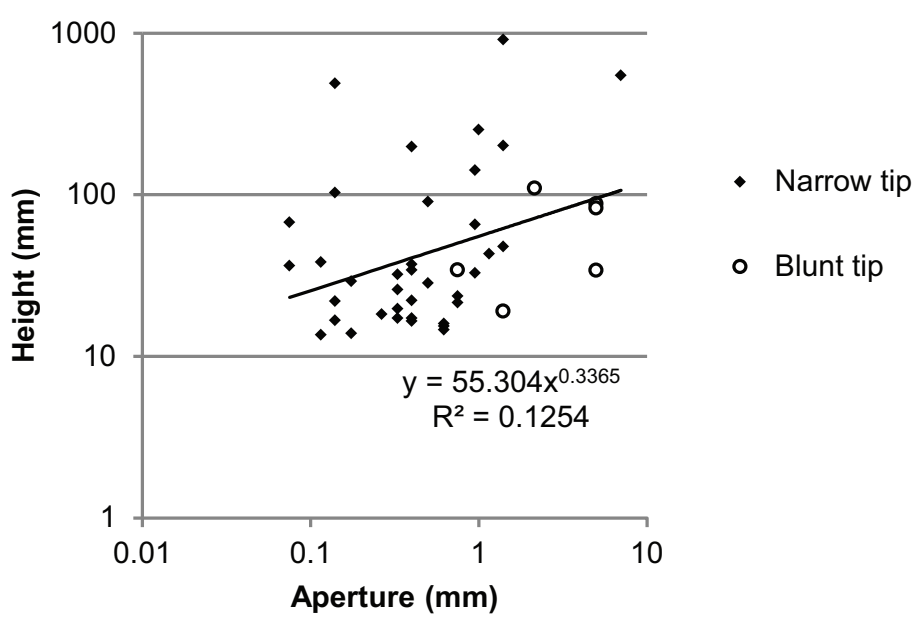

Figure 7. Vein height (or length, for layer-parallel fractures) versus aperture. Blunt-tip refers to fractures whose tips terminate at bedding planes or other layer-parallel features, enabling fracture widening without lengthening. Power-law equation fit to all fracture types combined. Poor correlation reflects the variety of aspect ratios observed. 

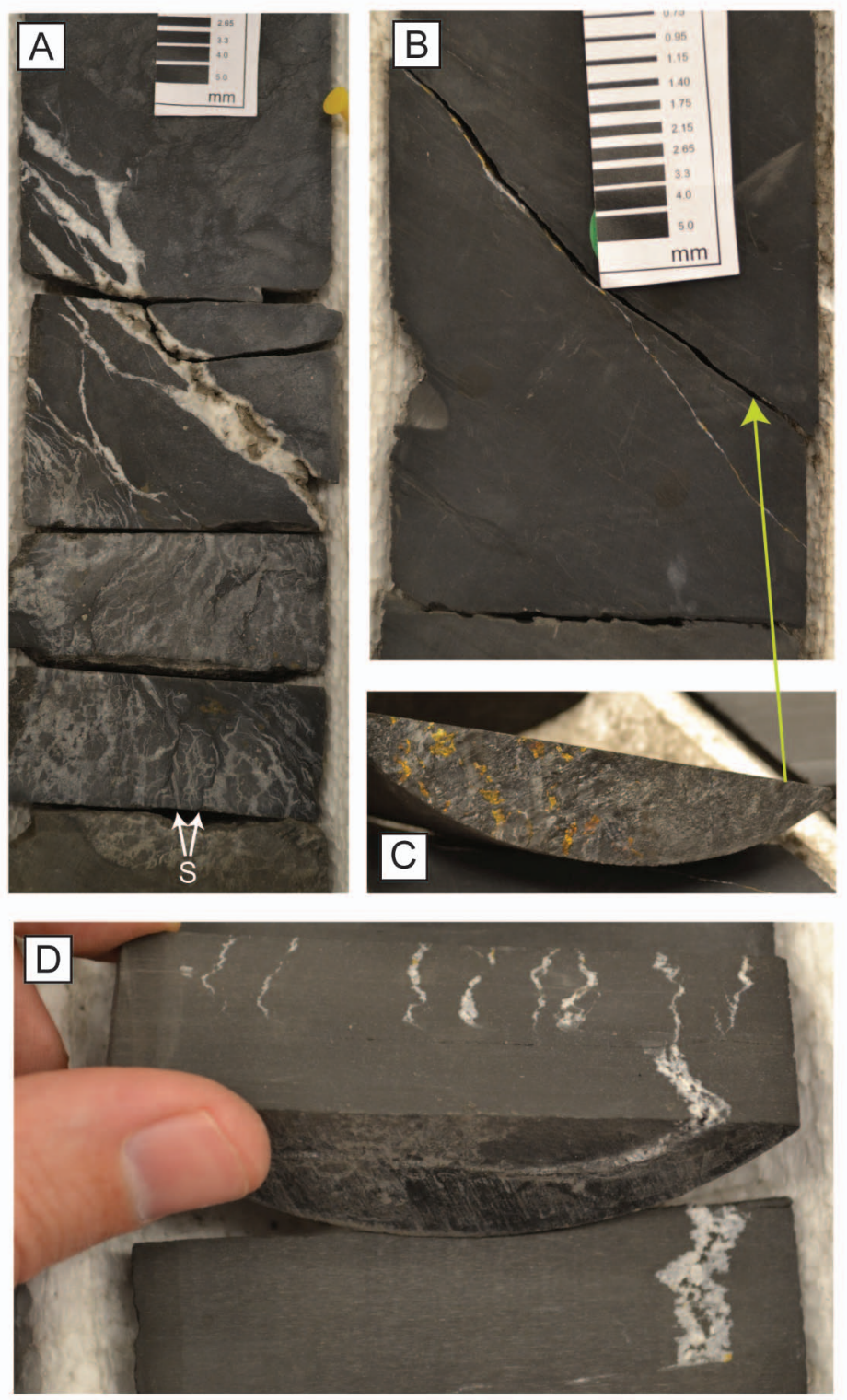


\section{Pyrite precipitation in shale}

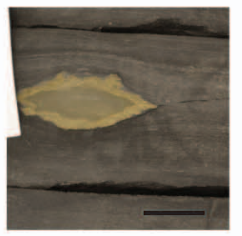

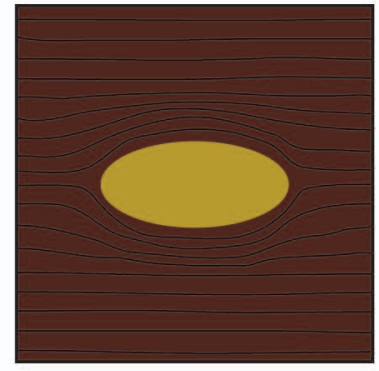

Displacive nodule

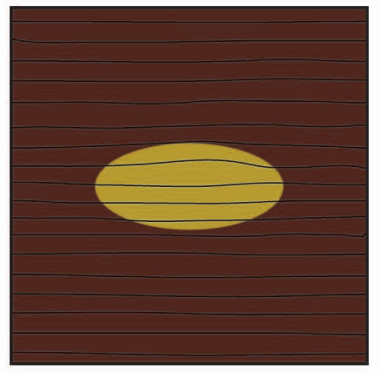

Replacive or pore-filling nodule

Fractures form during pyrite precipitation
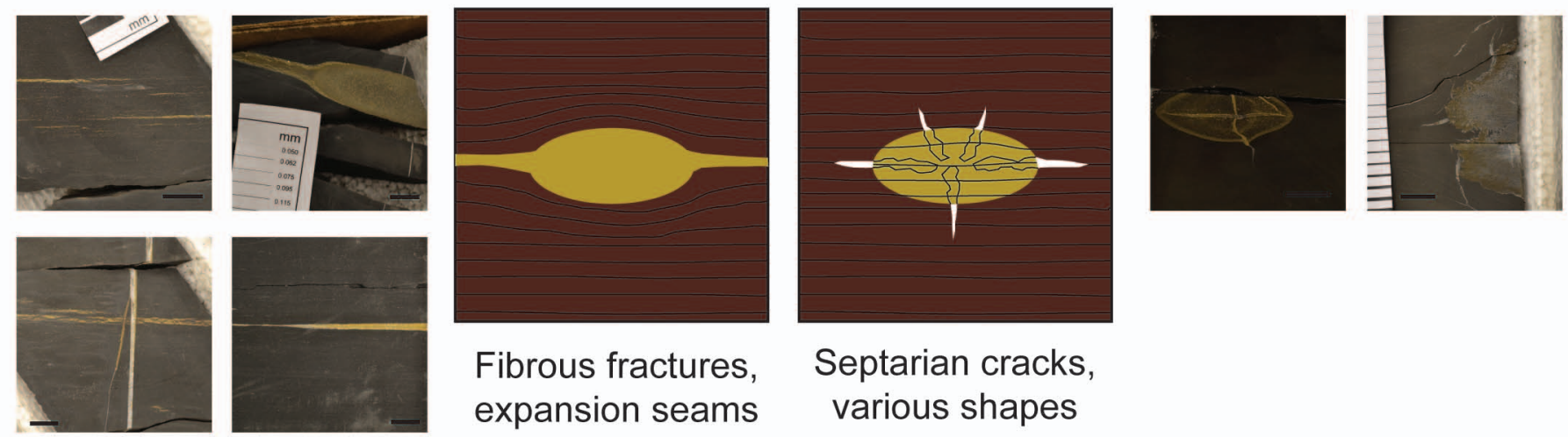

Fibrous fractures, expansion seams

Septarian cracks, various shapes

Fractures form after pyrite precipitation
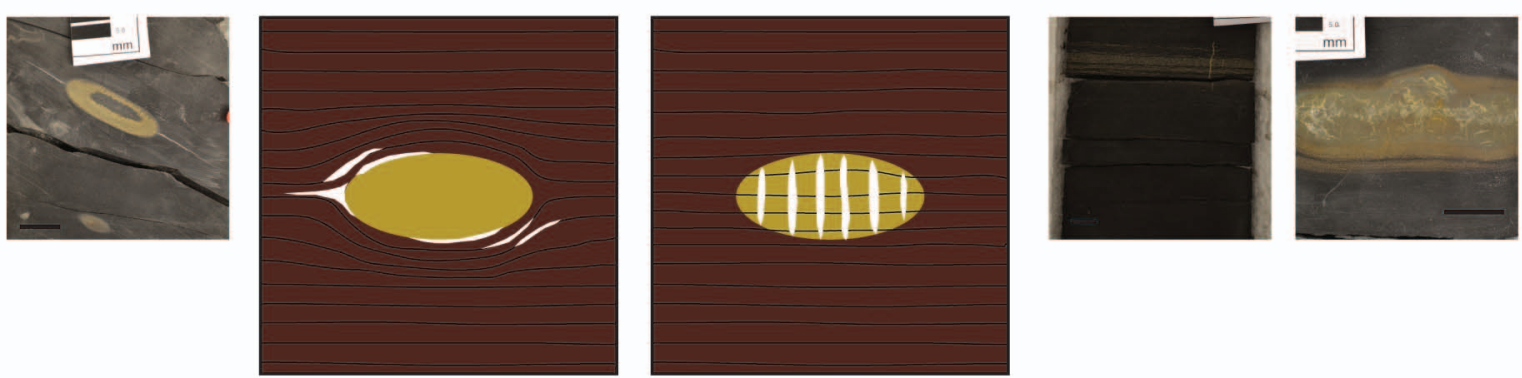

Stiff pyrite in compliant host shale 

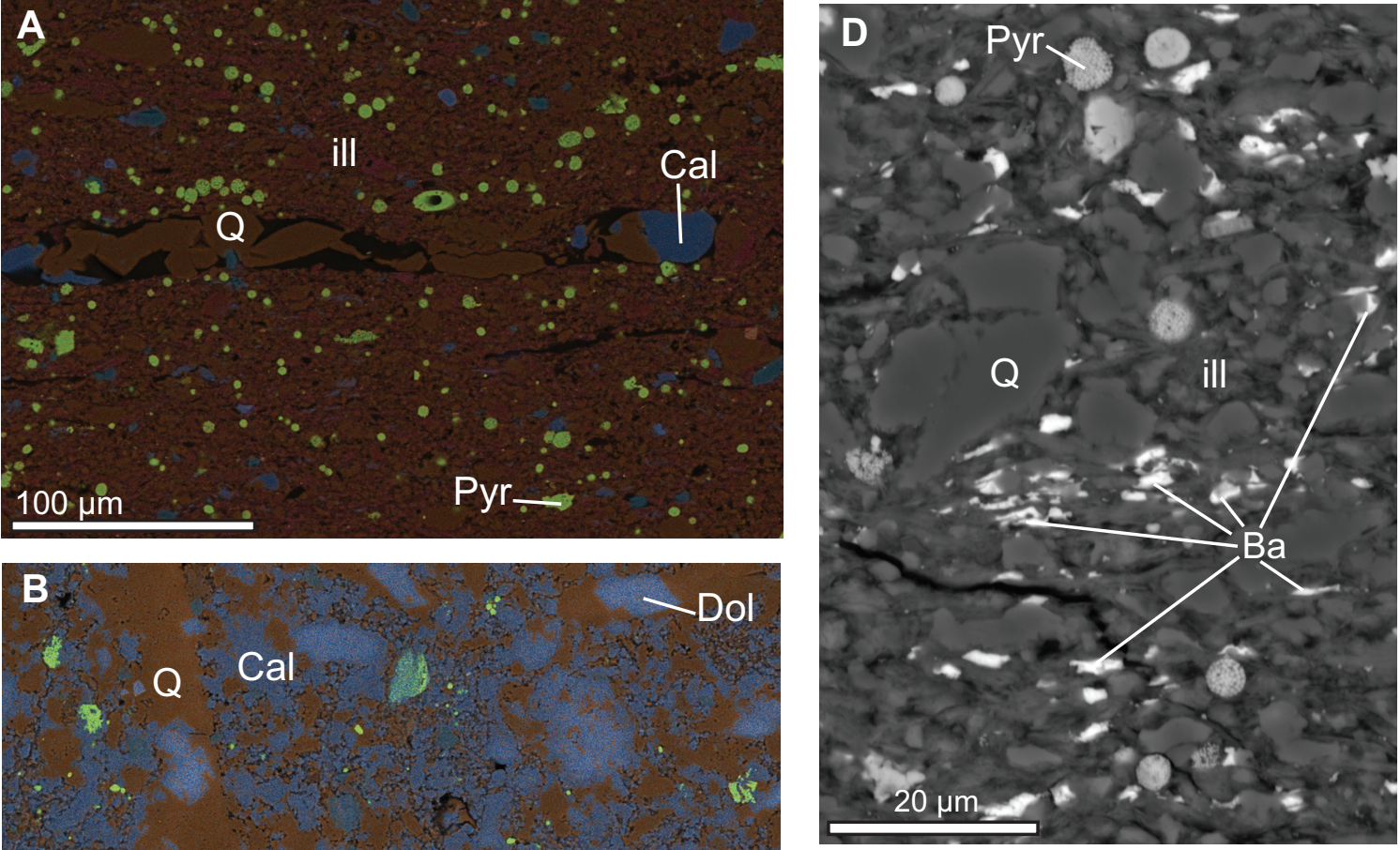

E

\section{$100 \mu \mathrm{m}$}
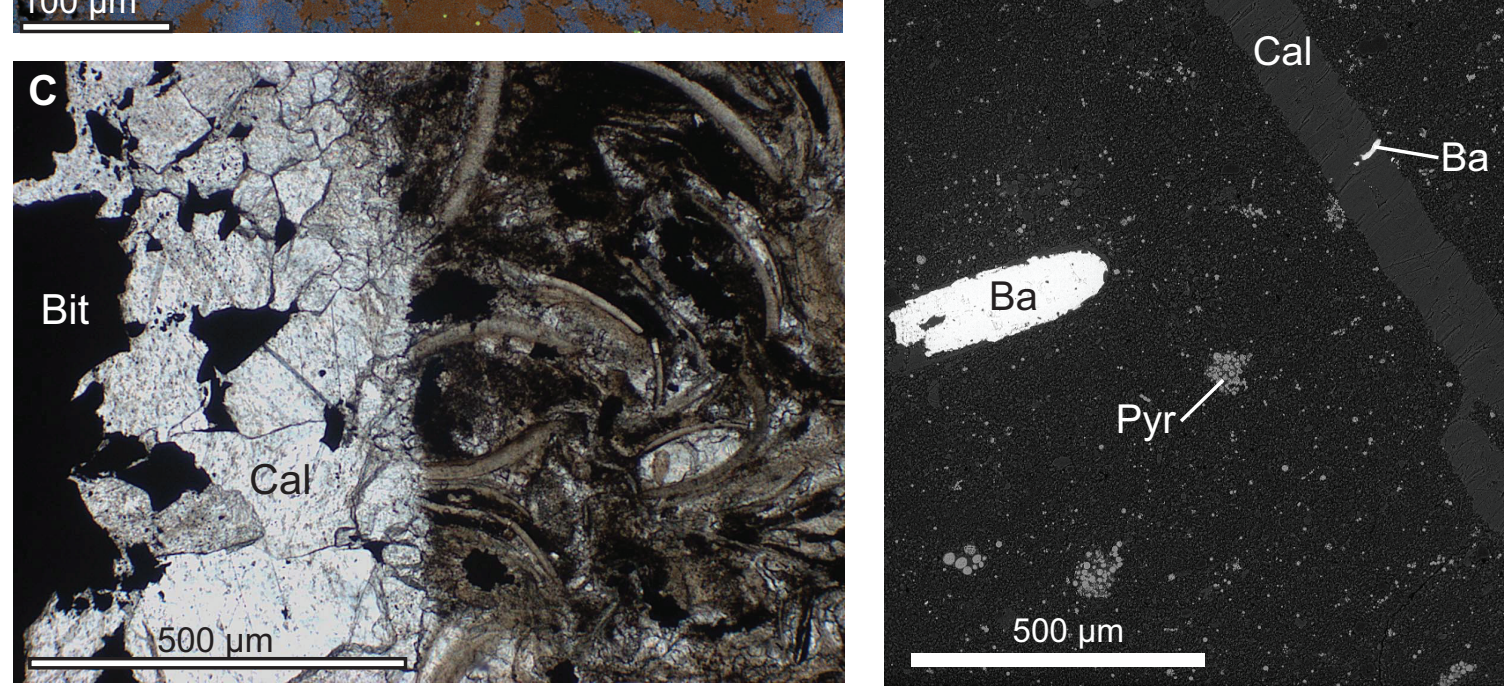

Figure 10. Host rocks. Ba: barite; Bit: bitumen; Cal: calcite; Dol: dolomite; ill: illite; Pyr: pyrite; Q: quartz. (A) EDS map of clay and pyrite-rich mudstone, Lower Marcellus, Core F, depth $5642.6 \mathrm{ft}$. Clay is primarily illite; note abundant silicate and carbonate detrital grains. Most pyrite is framboidal but blocky pyrite is also present. Note also blocky quartz cement within layer-parallel, elliptical pore. (B) EDS map of quartz- and dolomite-cemented marl, Upper Marcellus, Core S, depth $4840.0 \mathrm{ft}$. Abundant diagenetic dolomite and quartz is present; original sedimentary texture is faint. (C) Plane-polarized light image of fossiliferous rock hosting calcite-bitumen vein, Utica Shale, Core P, depth $8514.8 \mathrm{ft}$. (D) BSE image of clay, detrital silicate, and pyrite-rich mudrock, Upper Marcellus, Core A, depth 5548.9 ft. Note barite coating illite flakes. (E) BSE image of fossiliferous, pyrite-rich mudrock, Upper Marcellus, Core F, depth $5506.3 \mathrm{ft}$. Note barite filling fossil. 

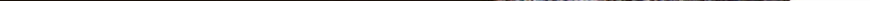


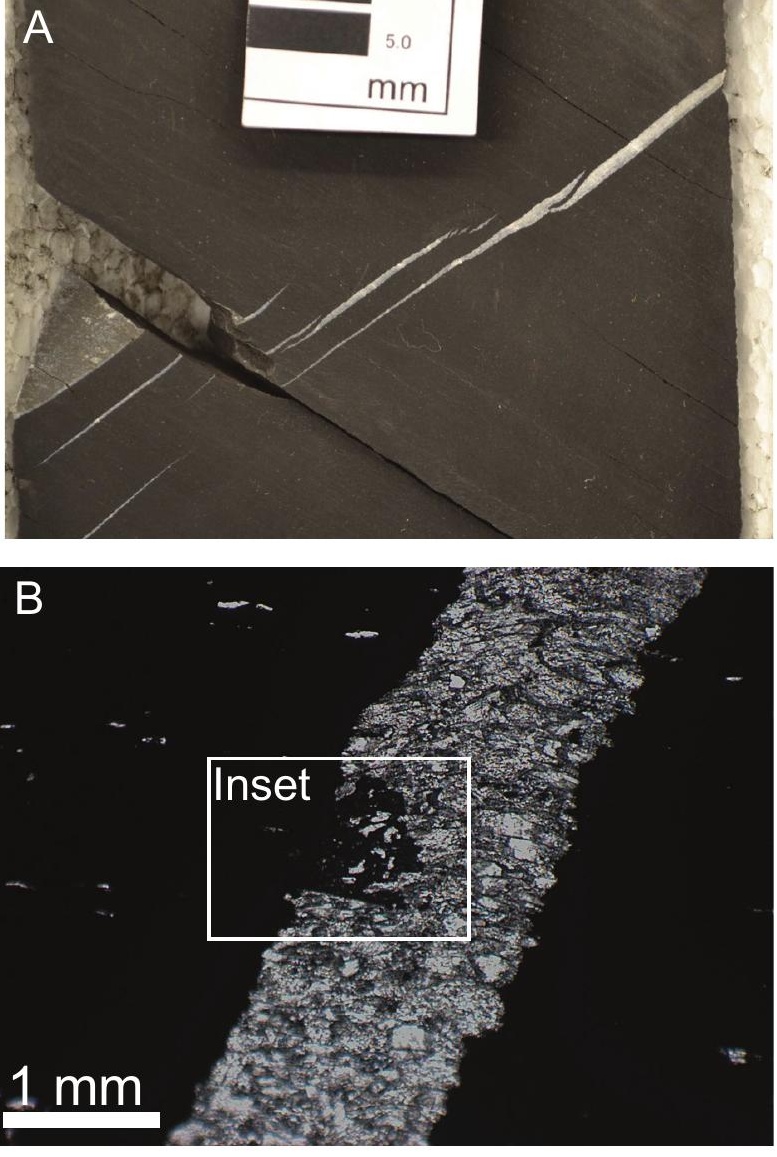

Inset

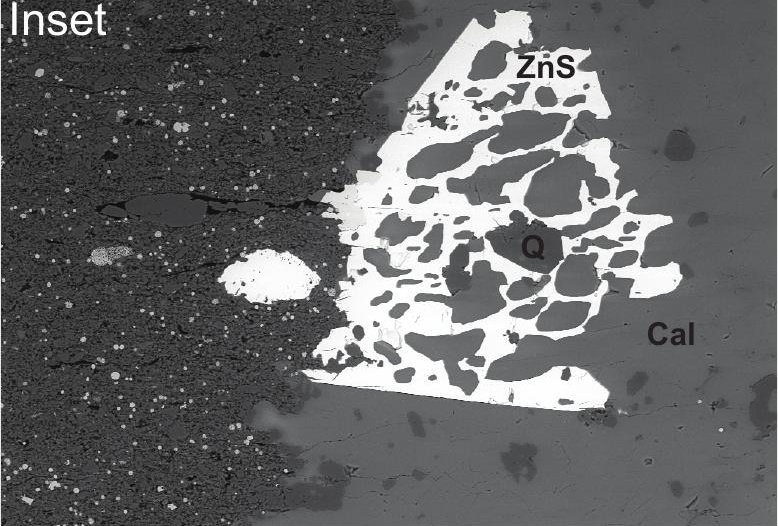



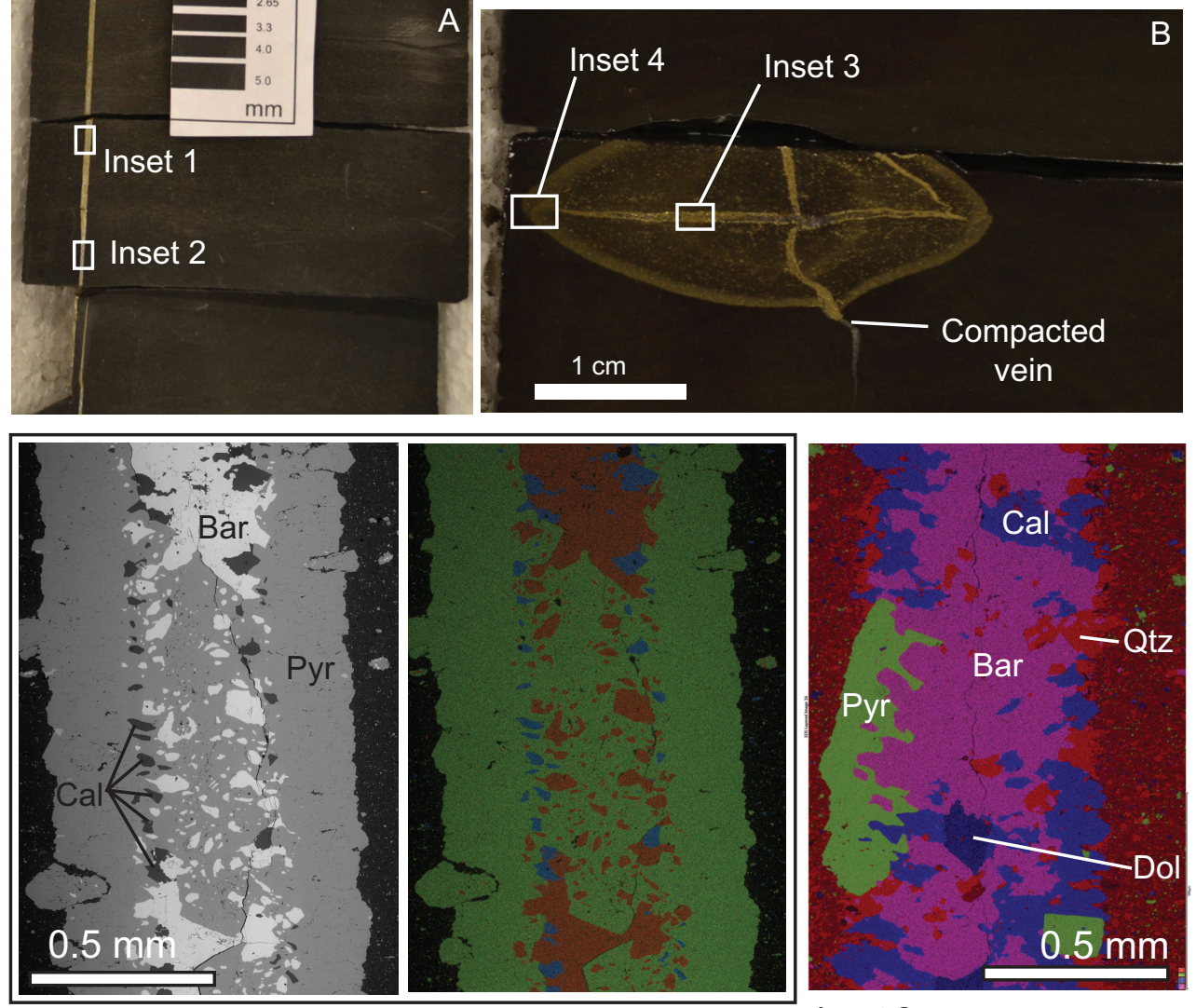

Inset 1

Inset 2

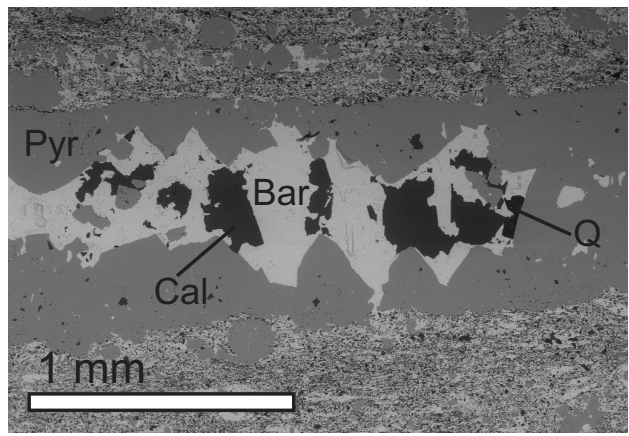

Inset 3

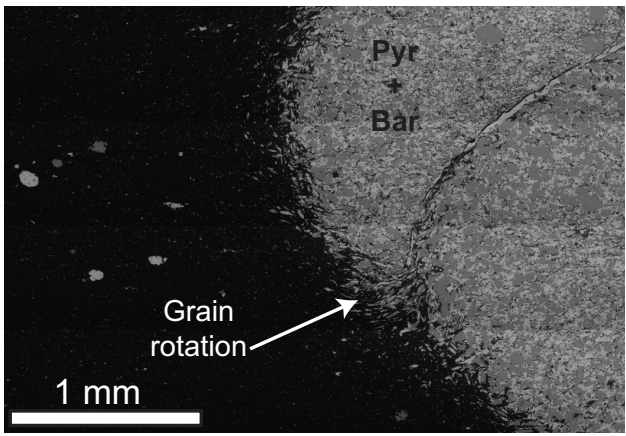

Inset 4

Figure 14. Vein filling minerals. Bar: barite; Cal: calcite; Pyr: pyrite; Q: quartz. (A) Vein with pyrite at margins and micro-blocky fill in the center, comprising pyrite, calcite, and barite crystals (Inset 1). Blocky texture suggests syntaxial fill (from the margins toward the center). Lower along the fracture (Inset 2) the aperture is narrower. Late dolomite is present near center of fracture. Trace quartz along the margins might reflect late-stage recrystallization; note the fracture walls are particularly crenulated where quartz is present. Core $A$, $5548.9 \mathrm{ft}$ (Upper Marcellus). (B) Layer-parallel vein within pyrite-barite concretion, Core S, depth $4829.6 \mathrm{ft}$ (Upper Marcellus). Rare example of polymineralic layer-parallel vein. Note the same apparent mineral precipitation sequence in (A) and (B) (Inset 3). Also note compacted vein and rotation of host sediment at margin of concretion (Inset 4). 

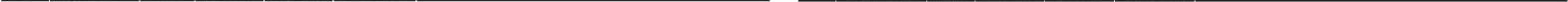
Mineral

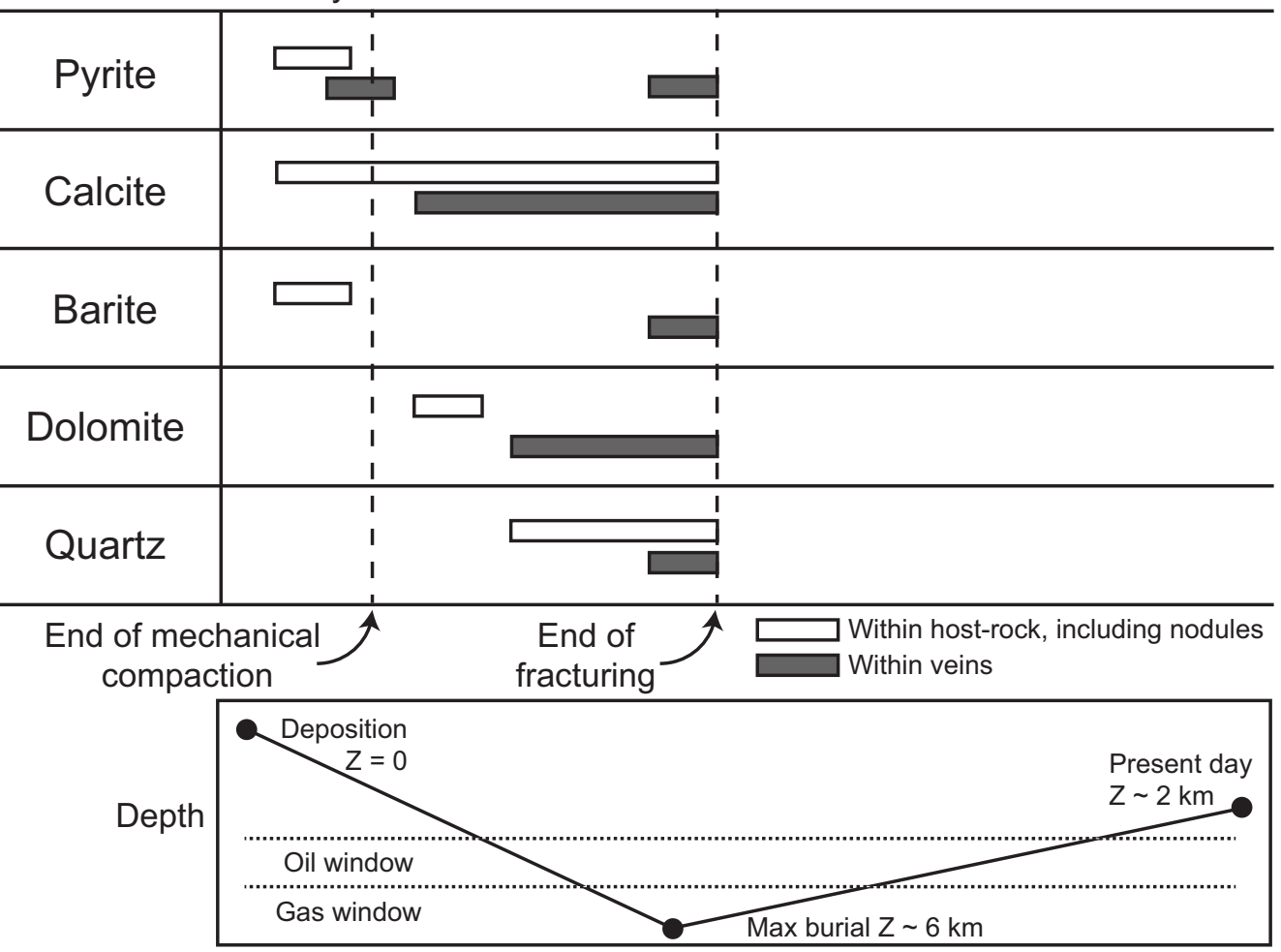

Figure 19. Paragenetic sequence and schematic depth-time curve for Marcellus Formation shale layers. Note fracturing ceases during or soon after maximum burial. Maximum burial depth approximated from Evans et al. (2014) and Wilkins et al. (2014). 
Initial sediment, post-compaction

Water

Carbonates

Silicates

$+$

Organic matter

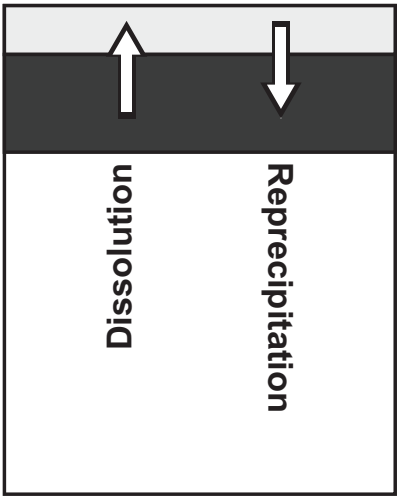

Begin fracture opening Continue fracture opening
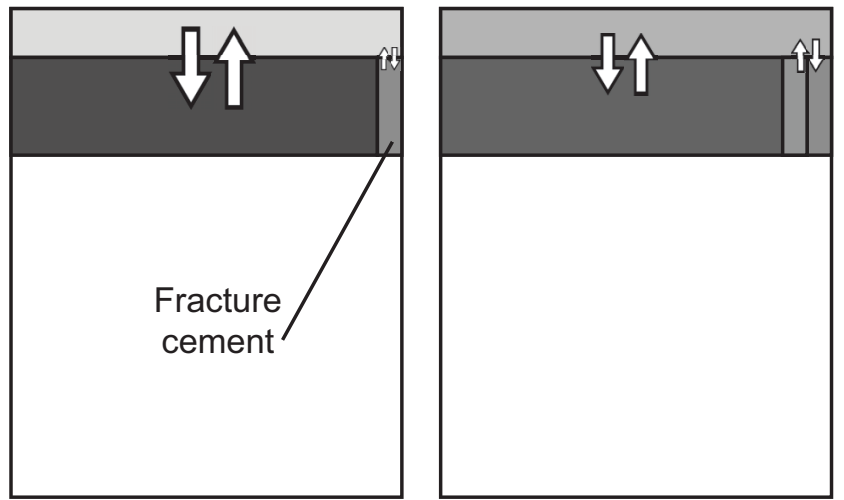

Time

Figure 20. Schematic of oxygen isotopic evolution model. Size of arrows represents relative contribution to dissolution-reprecipitation, which is proportional to the current volume of the component being dissolved or reprecipitated. Shade of water and carbonate portions represents oxygen composition (dark is heavy). Isotopic exchange with silicates and organic matter is neglected; see text. 


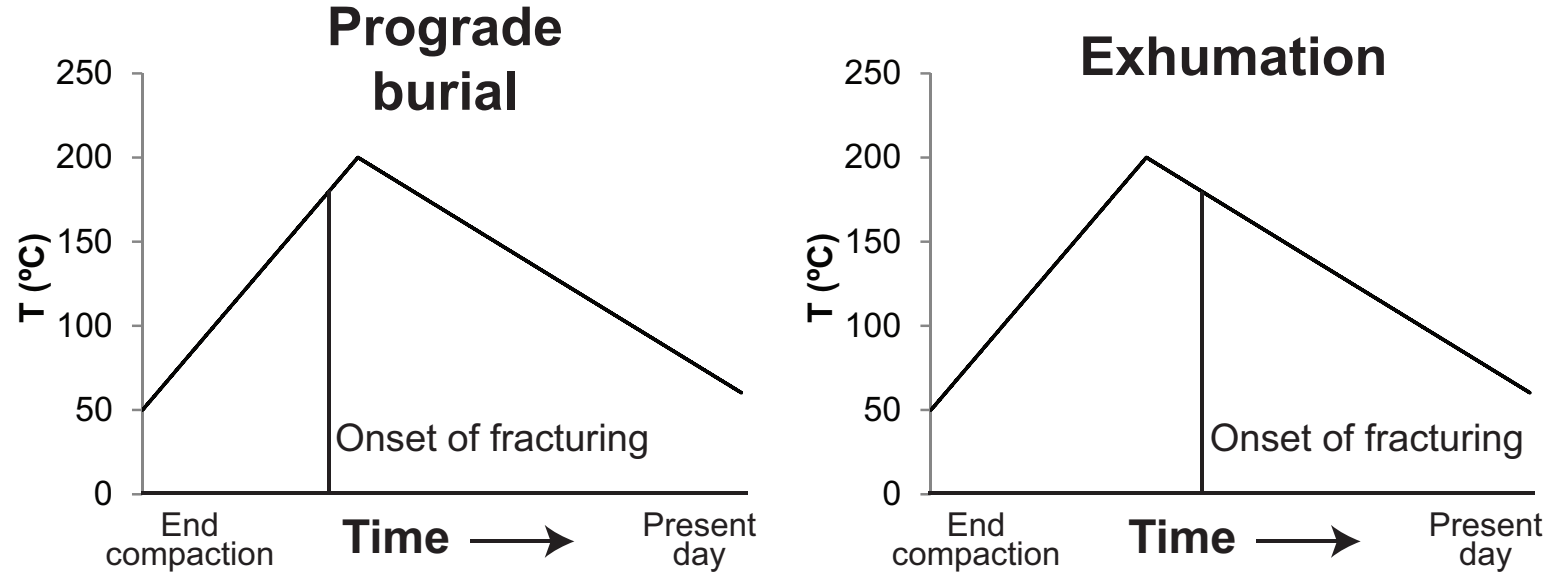

Isotopic exchange to present day
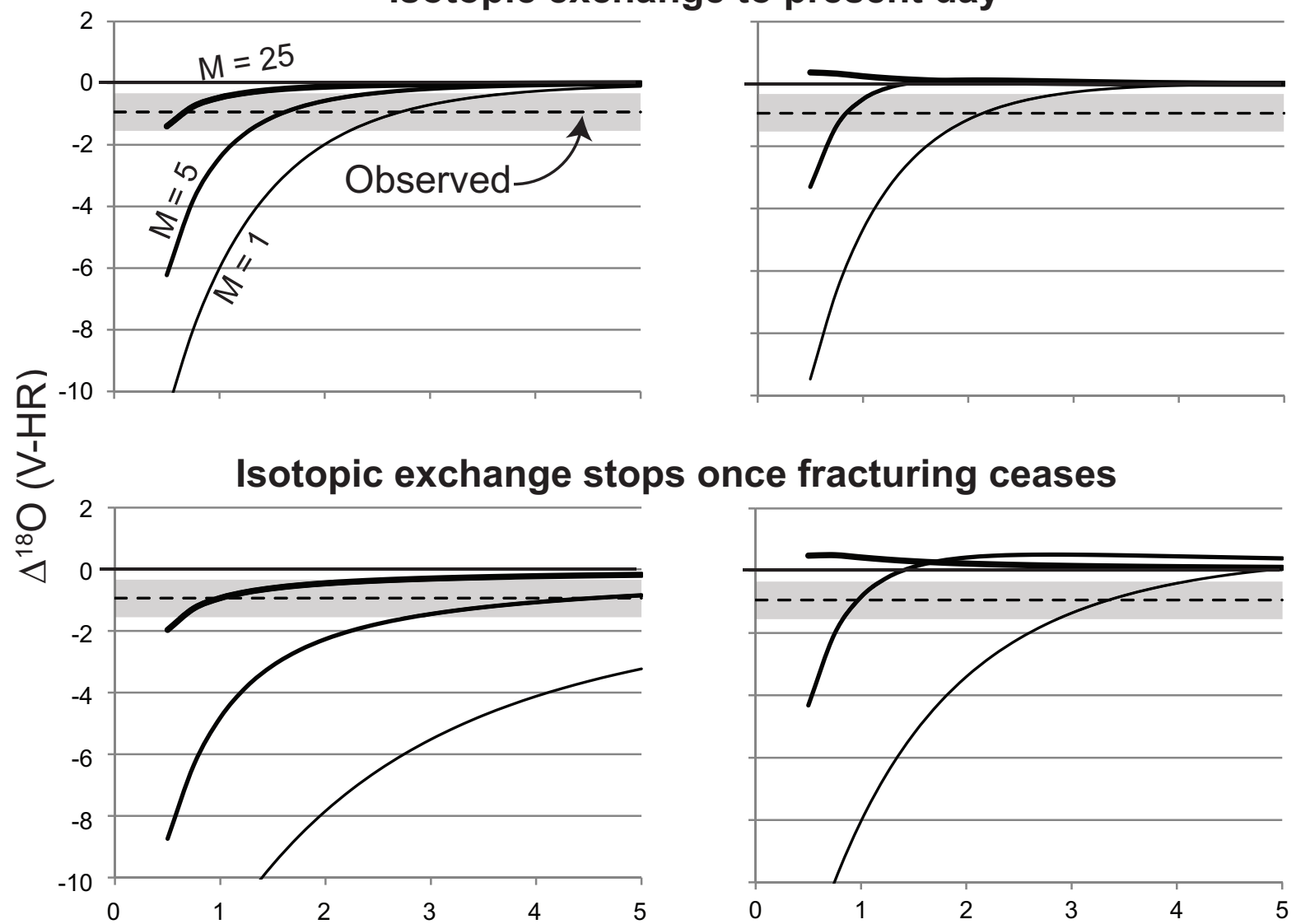

Cumulative volumes of host-rock carbonate dissolved, reprecipitated

Figure 21. Oxygen model output. Shaded area represents the observed variation (one standard deviation). $M$ is the ratio of carbonate to water in the host material. For fracture opening during prograde burial, note $\Delta^{18} \mathrm{O}(\mathrm{V}-\mathrm{HR})$ is near the observed $\sim-1 \%$ value over a wide range of carbonate volumes reprecipitated. For fracture opening during exhumation, note $\Delta^{18} \mathrm{O}(\mathrm{V}-\mathrm{HR})$ quickly homogenizes under cooling conditions. 


\begin{tabular}{|c|c|c|c|c|c|}
$\begin{array}{c}\text { Fracture } \\
\text { strike }\end{array}$ & $\begin{array}{c}\text { Fracture } \\
\text { dip }\end{array}$ & $\begin{array}{c}\text { Tip } \\
\text { morphology }\end{array}$ & Mine ral fill & $\begin{array}{c}\text { Crys tal } \\
\text { habit }\end{array}$ & $\begin{array}{c}\text { Relative } \\
\text { timing* }\end{array}$ \\
\hline NE & $\begin{array}{c}\text { Layer- } \\
\text { perpendicular } \\
\text { blunt against } \\
\text { bedding; } \\
\text { commonly wispy }\end{array}$ & $\begin{array}{c}\text { Calcite with: } \\
\text { dol, pyr, bit, qtz, } \\
\text { bar, por }\end{array}$ & $\begin{array}{c}\text { Blocky- } \\
\text { euhedral, } \\
\text { stretched }\end{array}$ & 2 \\
\hline NNW & $\begin{array}{c}\text { Layer- } \\
\text { perpendicular }\end{array}$ & $\begin{array}{c}\text { Gradual taper; } \\
\text { rarely blunt; } \\
\text { commonly wispy }\end{array}$ & $\begin{array}{c}\text { Calcite with: } \\
\text { dol, pyr, bit, qtz, } \\
\text { bar, por }\end{array}$ & $\begin{array}{c}\text { Blocky- } \\
\text { euhedral, } \\
\text { stretched, } \\
\text { fibrous }\end{array}$ & 2 \\
\hline N/A & $\begin{array}{c}\text { Layer- } \\
\text { parallel }\end{array}$ & Gradual taper & $\begin{array}{c}\text { Monomineralic } \\
\text { except in } \\
\text { nodules }\end{array}$ & $\begin{array}{c}\text { Fibrous, } \\
\text { rarely blocky }\end{array}$ & 1 \\
\hline
\end{tabular}




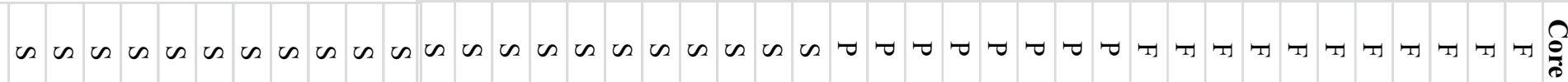

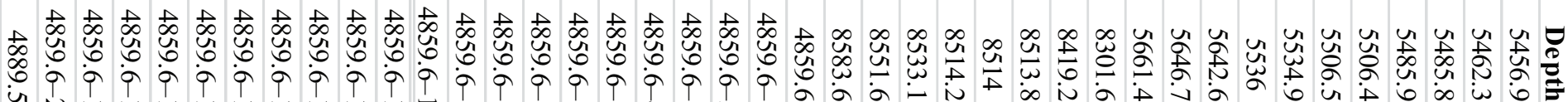

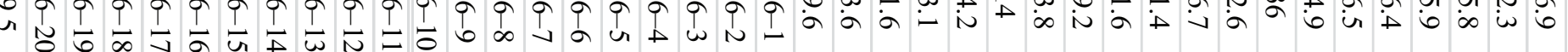

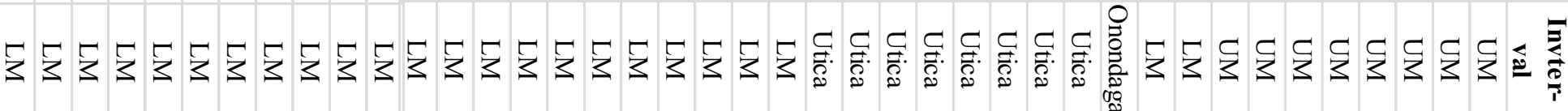

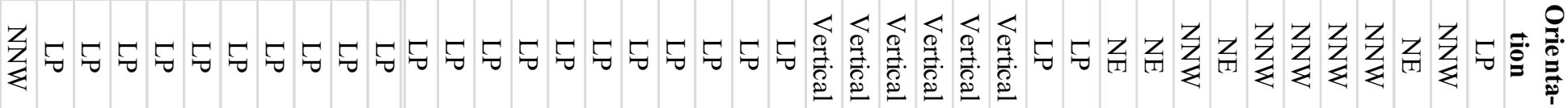

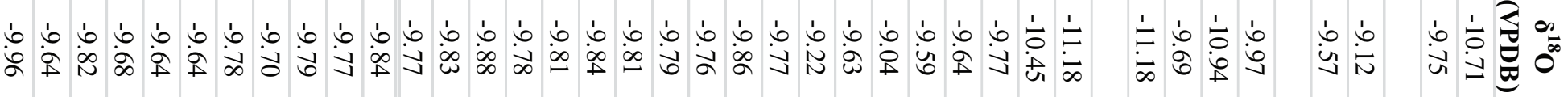

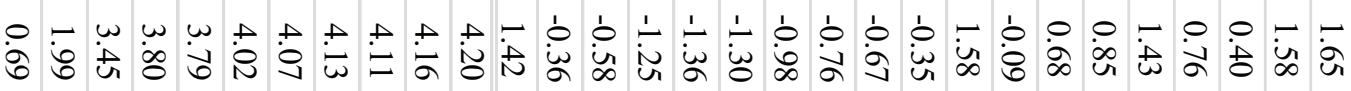

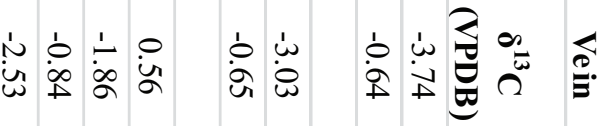

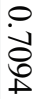

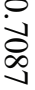

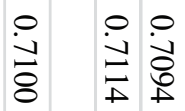

ذأ

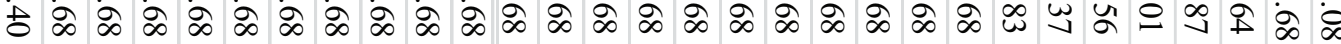

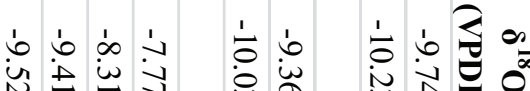
ن்

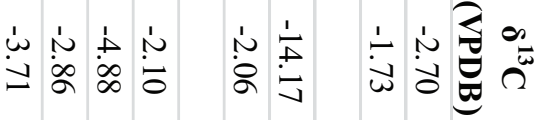

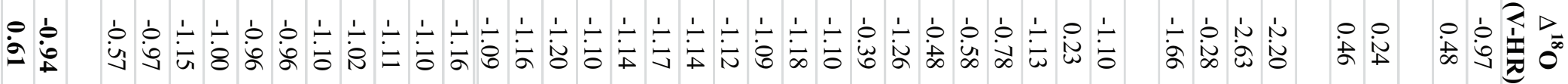

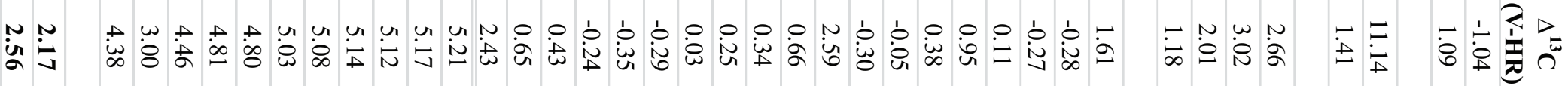

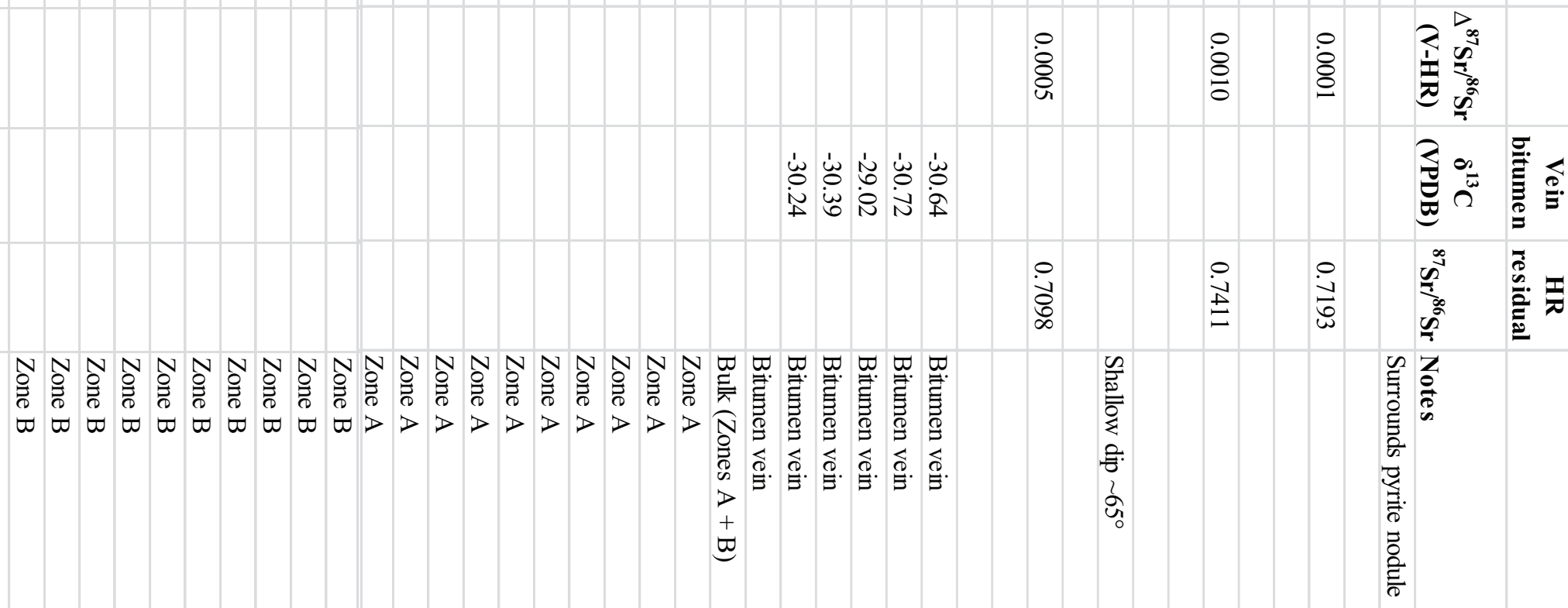

